\title{
Muhammad y el monacato sirio
}

\author{
José María BlÁzQuez Martínez \\ Universidad Complutense de Madrid - Real Academia de la Historia
}

\section{RESUMEN}

En este trabajo se comparan puntos fundamentales de la religiosidad del Corán con los del monacato sirio. Para S. Juan Damasceno, que vivió muchos años en la corte de los Omeyas y desempeñó altos cargos, Muhammad es un hereje cristiano; los grandes investigadores protestantes del siglo XX, como Harnack, Schlatter, o Wellhausen, afirman que era un ebionita, esto es, un judío-cristiano heterodoxo de los que vivían en Palestina y Siria, tesis que aceptó el gran teólogo católico H. Küng, partidario de un diálogo con el Islam. Muhammad llevó, al principio, una vida en la montaña, muy parecida a la de los monjes cristianos. No se puede dudar de un fuerte influjo del monacato palestino y sirio en la religiosidad de Muhammad, como indica D. J. Sahas, excelente conocedor de S. Juan Damasceno. La religiosidad de Muhammad, del monacato sirio y de Jesús, tienen un fuerte carácter social, al igual que la de los grandes profetas de Israel. El presente estudio confirma la frase de Seyyed Husseyn Nasr, de que los primitivos musulmanes son monjes que no guardan el celibato.

Palabras clave: Influjos monacato sirio. Corán. Infierno. Juicio Final. Demonología. Angeología. Paraíso. Oración. Ayuno. Limosna. Prohibición de alimentos. Peregrinaciones e inspiraciones. Eucaristía. Cristología. Ebionitas. Judeo-cristiano. Montaña. Monjes.

\section{Muhammad and Syrian Monasticism}

\begin{abstract}
This paper compares fundamental aspects of religiousness in the Qur'an with that of Syrian Monasticism. Muhammad is a Christian heretic according to Saint John of Damascus, who lived many years in the Umayyad court, where he held important posts. The great protestant investigators of the $20^{\text {th }}$ century -Harnack, Schlatter, Wellhausen- maintain he was an Ebionite, in other words, a heterodox Jewish Christian, who lived in Palestine and Syria. A thesis accepted by the great catholic theologian H. Küng, a supporter of dialogue with Islam. Muhammad lived at the beginning a mountain life, very similar to that of Christian monks. A strong influence of Palestinian and Syrian Monasticism in Muhammad's religiousness can't be put in question, as D. J. Sahas, an excellent connoisseur of Saint John of Damascus and Muhammad, points out. The religiousness of Muhammad, of Syrian Monasticism and of Jesus have strong social character, like that of the great prophets of Israel. This paper confirms the sentence of Seyyed Husseyn Nasr, that primitive Muslims were monks who did not keep up with celibacy.
\end{abstract}

Key words: Palestinian Monasticism influence. Qur'an. Hell. Last Judgement. Demonology. Paradise. Angeology. Fasting. Alms. Food prohibition. Peregrinations. Revelations and Inspirations. Eucharist. Christology. Ebionite. Jewish Christian. Mountain. Monks.

Sumario: 1. Muhammad y el monacato sirio. 2. Los monjes de Siria y el Corán. 


\section{MUHAMMAD Y EL MONACATO SIRIO}

En un reciente trabajo hemos estudiado los posibles influjos del monacato palestino en el Corán, siguiendo la tesis de Tor Andrae, que hace muchos años señaló fuertes influjos de la Iglesia y del monacato sirio en el Corán, lo que igualmente señaló recientemente D. J. Sahas. En este segundo trabajo se comparan aspectos fundamentales de la religiosidad del Corán con los del monacato sirio: Infierno, Juicio Final, Demonología, Angeología, el Paraíso, Oración, Ayunos, Limosna, prohibición de alimentos, Resurrección y otros.

Todas las religiones tienen grandes puntos de contacto, principalmente las religiones monoteístas, judaísmo, cristianismo e Islam, que adoran al mismo Dios, el Dios de Abraham, de Isaac y de Jacob (fig. 1).

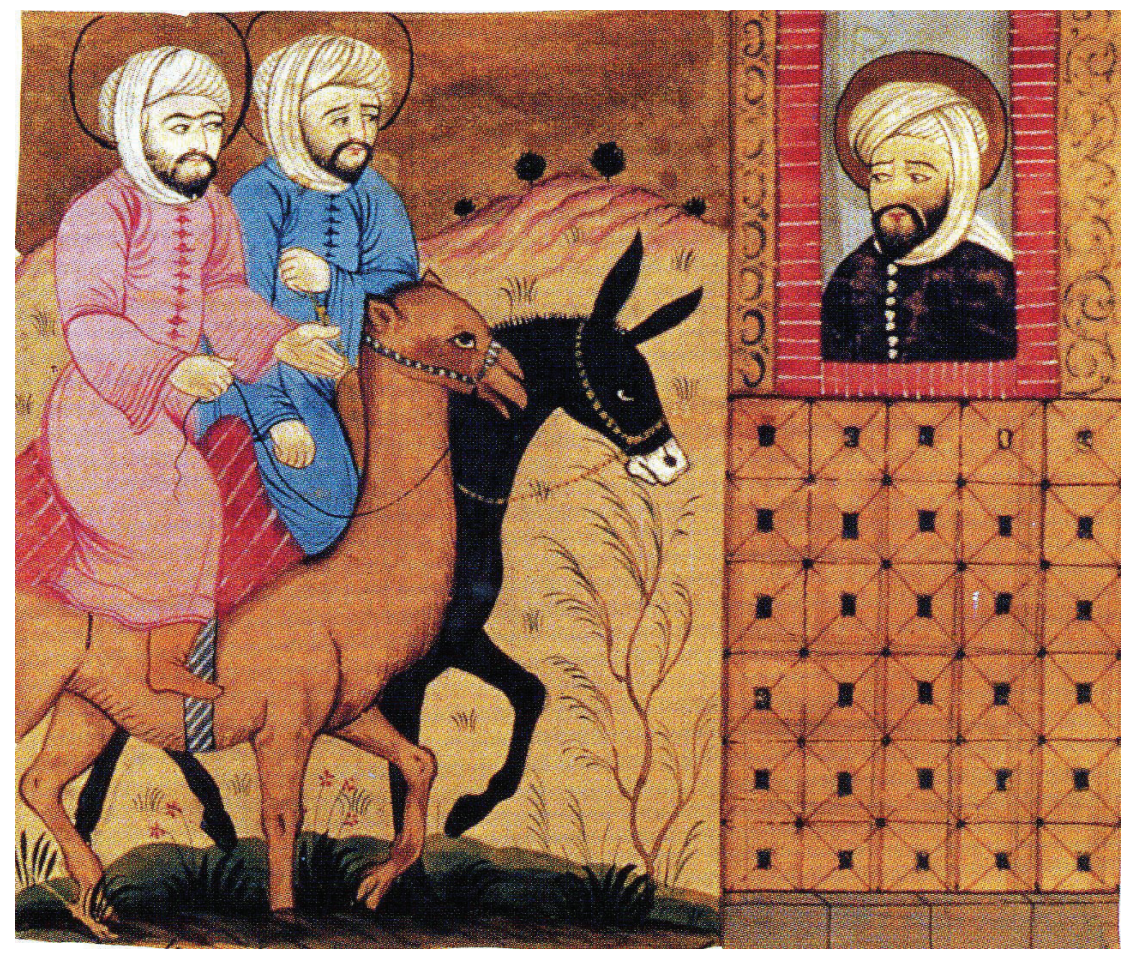

Fig. 1. Muhammad y Jesús visitan a Abraham. Manuscrito. Royal Library. Edimburgo.

El cristianismo aceptó el Antiguo Testamento. Jesús afirmó que no vino a borrar la Ley, sino a cumplirla (Mt. 5.17). Cumplió los preceptos de la Ley mosaica. Baste recordar que Jesús celebró la Pascua con sus discípulos poco antes de morir (Mt. 26.17-35; Mc. 14.12-36; Lc. 22.1-23; Jn. 13.1-2), que era la principal fiesta de los judíos (Ex. 12.13.23.27; Nu. 9.1-13; Jos. 5.10; 2 Re 23.22; Jn. 18.28). Muerto Jesús, 
los discípulos seguían frecuentando el templo. Pedro y Juan subían al templo a la hora de la oración (Hch. 3.1), y Santiago, el hermano de Jesús, se pasaba todo el día orando en el templo hasta que fue asesinado en el año 62, según el historiador judío Josefo (Antigüedades Judias, XX.199-203).

Muhammad aceptó del judaísmo el Pentateuco, los Salmos y los profetas, aunque amplió el número de profetas, David, Salomón, y tuvo un altísimo concepto de Jesús y de su madre, María, como se verá más adelante. Sin embargo, las tres religiones monoteístas han mantenido luchas entre sí.

Es una vergüenza que el cristianismo se haya enzarzado, desde el primer momento, en luchas feroces contra diferentes grupos, contadas en la Carta de Clemente Romano, del año 97, a las que siguieron otras muchas, ${ }^{1} \mathrm{y}$ en la Antigüedad, las persecuciones de cristianos contra judíos desde el primer momento de la aparición del cristianismo.

Este ataque es uno de los aspectos más negativos de la Iglesia a través de los siglos, no haber llegado a un modus vivendi con sus raíces, como ha sabido hacer el Islam. Al parecer, fue el apologista Aristón de Pella el primero que difundió por escrito el cristianismo contra el judaísmo. Demostró, según Orígenes (c. Cels. 4.52), que en Cristo se habían cumplido las profecías del Antiguo Testamento. La Apología se ha perdido. La más antigua apología conservada contra los judíos es el Diálogo con Trifón de Justino, que quiere probar -ayudado en los profetas- que la verdad cristiana existía antes de Cristo. Claudio Apolinar, obispo de Hierápolis en tiempos de Marco Aurelio (161-180), según Eusebio (HE. 4.27), escribió dos libros contra los judíos.

Tertuliano escribió una obra titulada Contra los judios, que es una disputa entre un cristiano y un prosélito judío. En ella se demuestra que el Antiguo Testamento, por no aceptar Israel a Cristo, ha perdido todo valor. El profeta Daniel predijo la destrucción de Jerusalem. Hipólito de Roma es el autor de una Demostración contra los judios, que responsabiliza a los judíos de todas sus desgracias por los crímenes que cometieron contra el Mesías. Novaciano, según Jerónimo (De vir. ill. 70), escribió tres libros contra los judíos: De circuncisione, De sabbato y De cibis iudicis. Juan Crisóstomo, entre los años 386 y 382, pronunció ocho homilías contra los judíos, que eran judeocristianos. En época bizantina la literatura antijudía continuó.

Los tres grandes genios religiosos de la humanidad son Jesús, ${ }^{2}$ Muhammad $^{3}$ y Buda. ${ }^{4}$ Los dos primeros no tienen conciencia de ser fundadores de ninguna religión. Jesús, como se indicó, no vino a borrar la Ley judía, sino a cumplirla. Muhammad creía que la revelación divina hecha a Abraham, a Moisés, y a los profetas, se había desviado, y vino Jesús a volverla a su verdadero estado, pero también se desvió después, aceptando dogmas desconocidos como la divinidad de Jesús y la Trinidad, y llegó él, el último profeta enviado por Dios, a enderezarla. Jesús era un apocalíptico;

1 BlÁzquez 2006; ID. 2007; ID. 2007a; ID. 2008; ID. 2009; ID. 2010; ID. e.p.; SuÁREZ 2002, 17-26.

2 Sobre Jesús véanse los trabajos de Crossan 1994; Schillebeekx 1981; RUIz 2004 y ARnÁldez 1990.

3 Sobre la vida de Muhammad, la biografía es inmensa. Unos cuantos títulos importantes son: WATT 1958; ID. 1959; Ling 1989; GaUdEFROY-DESMOMBYNES 1990 y Vernet 1987. Sobre la vida musulmana de Muhammad, la primera y más importante, redactada a base de tradiciones orales, es la de Ibn-Ishaq's Sirat Rasul Allah, muerto en 768; véase Guillaume 1955. Recoge lo anterior el historiador persa del s. IX MuHAMMAD IBN GARIR AL-TABARI 1989.

4 BAREU 1989. 
igualmente, fue calumniado para llevarlo a la muerte (Mt. 26.59-61; Mc. 14.56; Jn. 10.20-21). Muhammad tenía un fuerte influjo cristiano. Fue calumniado por los cristianos, acusándole de falso profeta y de mujeriego. Las calumnias sobre Muhammad son de origen bizantino. Bizancio y el cristianismo tardaron tiempo en dar importancia al Islam. Lo consideraron -al principio- un cristianismo descafeinado. Las calumnias han llegado hasta la actualidad. El obispo de Roma, Benedicto XVI, lo consideraba una religión falsa y peligrosa. No había leído nunca un libro sobre el Islam. También se ha atacado a Muhammad por la poligamia. Todo el Antiguo Testamento acepta sólo la poligamia, salvo Jesús, que era partidario del matrimonio monógamo (Mc. 10.6-9). Las Sagradas Escrituras no conocen el celibato. Jesús no trató el tema (1 Cor. 7.25), ni lo recomendó a nadie. El texto que el papa polaco (Mt. 19.12) aplica al celibato sacerdotal es una burda y cínica interpretación suya, se refiere al divorcio. En lo referente a la mujer, tanto Jesús como Muhammad fueron avanzados y casi revolucionarios. Jesús anduvo rodeado de mujeres, que le servían. En las iglesias de Pablo, la mujer desempeñó un papel importante. Muhammad concedió a la mujer el derecho de herencia y de divorcio, que en Occidente no se admitió hasta el s. XIX, hablar en las asambleas de Medina y acompañar en las guerras.

Muhammad, con respecto a las mujeres, fue un moderado. Nunca tuvo más de nueve al mismo tiempo. David tuvo siete mujeres, más otras dos, más las concubinas (2 Sam. 3.2-5; 1 Cr. 3.1-4). Pronto, la situación favorable a la mujer decayó, tanto en el cristianismo como en el Islam. En el cristianismo, poco después de la muerte de Pablo, y en el Islam, por influjo de las cortes bizantinas y sasánidas, en las que la mujer estaba recluida y usaba velo.

Muhammad estaba completamente convencido de la verdad de su revelación.

El Corán es uno de los grandes libros de espiritualidad de la humanidad, que ha proporcionado alimento espiritual durante muchos siglos a millares de fieles, como el Antiguo Testamento para judíos, cristianos y musulmanes, el Nuevo Testamento para los cristianos, los Vedas y otros libros para los indios, el Canon tibetano y otros muchos libros para los tibetanos. La mística musulmana ha durado casi mil años. La cristiana siempre tuvo una fuerte oposición en el catolicismo oficial.

Ha dado lugar a la mística musulmana, ${ }^{5}$ que es la cumbre de la mística, de fuerte influjo en la cristiana, como en San Juan de la Cruz y en los alumbrados españoles. La cultura musulmana ha producido, además, un arte fabuloso de todo tipo, allá donde ha estado. ${ }^{6}$ Bagdad $^{7}$ y Córdoba ${ }^{8}$ son, en el s. X, los dos centros culturales mayores

\footnotetext{
5 Véanse los trabajos de Nicholson 2008; Granlich 2004; Shimmel 2002; Ernst 1999; MassignON 1999; Asín Palacios 1941; ID. 1981; ID. 1981a; ID. 1990; Pareja 1975; López-Baralt 1990; Vitray-Meyerovitch 2002; Abumalham 2005; Baldicks 1989; y Skali 2006. Sobre María: Cuerda Plaza 2002. Sobre el Corán: Bell - Watt 1987, y las introducciones de Vernet, ed., 1991, 9-52 y Cortés, ed., 2005, XI-LXIX. Se sigue aquí, en las citas del Corán, la traducción de Vernet, en casos adaptada por nosotros mismos. La tesis de que la mística musulmana tenía raíces cristianas (así en Nicholson y Massignon) la juzgamos dudosa, pues los grandes ascetas de Egipto, Siria, Palestina y Constantinopla no son místicos.

6 Cf. Papadopoulo 1977; Hallstein - Delius 2001; Stierlin 2002; Robinson 2007; Atil, ed., 1980; Scerrato 1972; Budert - Günler Lerch 1998; Akurgal, coord., 1981.

7 Gabrieli et alii, 1988.

8 Provençal 1950; VV.AA. 2001; Moreno 2006; Fierro 2011.
} 
del mundo y con mayor proyección cultural. El renacimiento cultural de la Edad Media cristiana es producto de los traductores de Toledo, que dieron a conocer a la cristiandad occidental el pensamiento de los autores clásicos. Se insiste frecuentemente, por los dos últimos papas, en que las raíces de Europa son cristianas, como sostiene uno de los mayores investigadores de la Tarda Antigüedad de la Universidad de Princeton, P. Brown. ${ }^{9}$ Más bien, como propusieron los obispos católicos belgas, son cristianas, judías y musulmanas.

Grandes especialistas en los orígenes del Islam han señalado el fuerte influjo del cristianismo sirio en el Islam, y concretamente el monacato cristiano. Este influjo no le quita nada a la originalidad del mensaje religioso de Muhammad. Tor Andrae, ${ }^{10} \mathrm{en}$ 1955, indicaba que le importaba ante todo aportar las pruebas de la originalidad de la piedad escatológica y ascética de Muhammad. Interesa a este autor la cuestión del origen de la materia de los relatos coránicos y el problema del vocabulario teológico del Corán. No puede discutir en detalle el hecho de que los elementos haggádicos de los relatos del Corán provienen, en lo esencial, de una información judía y de que el desarrollo espiritual en Medina se ha dado bajo una fuerte influencia judía. A Tor Andrae le interesa señalar que muchos de los haggádas coránicos habrían sido apropiados por la Iglesia siria. No se puede dudar que la fuente de los relatos coránicos debe encontrarse en la literatura de las Iglesias sirias. Tor Andrae recuerda algunas leyendas.

La leyenda coránica de Adán debe ser de origen cristiano. Según la leyenda judía, los ángeles quieren ser adoradores de Adán, lo que prohíbe el propio Adán. Según el Tesoro sirio, se manda a los ángeles prosternarse ante Adán. Los ángeles malos lo rehusaron. Los escritores sirios presentan este motivo de una manera próxima a la leyenda coránica Barhadh bechabba 'Asbaya. La polémica de Muhammad con los judíos, en gran parte, toma los argumentos de la Iglesia en su lucha contra los judíos. Se cree que se deben buscar los modelos cristianos o del Corán en las doctrinas más o menos gnósticas. Los conceptos coránicos sobre este punto están muy extendidos entre los teólogos sirios. La acusación de Muhammad a los judíos de fabricar las Sagradas Escrituras se encuentra ya en Epifanio de Salamina (Haer. XVIII), dirigida a los judíos fieles a la Ley en una secta, la de los Nazareos.

La misma acusación hicieron los cristianos contra los ebionitas, contra Elxai, y principalmente contra Marción. Los teólogos sirios han dirigido la misma acusación contra los judíos, con ocasión de las diferencias de las genealogías y de la cronología, entre la versión de los 70 y el texto hebreo.

Muhammad conoció estas acusaciones de los cristianos. Los judíos habían suprimido en la Torá los pasajes que se refieren al profeta de los árabes, pero habían cometido un error. Tor Andrae ha demostrado la relaciones claras entre la lengua del Corán y la lengua de las iglesias cristianas de Siria. Los escritores cristianos en la Edad Media han inventado, según la leyenda de Bahira, la historia de un monje nestoriano mentor de Muhammad. La triada Dios-Jesús-María, la polémica de Muhammad

9 Véase Brown 1997.

10 Andrae 1955. Sobre Siria: BRock, coord., 1984, principalmente el capítulo VII, obra de JuYNBOLL (1984, 9-21). Sobre Arabia: IBRAHIM AL-GHABBAN 2010. 
contra la expresión Cristo-Dios, la reproducción de las diversas leyendas apócrifas sobre la infancia de Jesús, probarían una relación posterior con la Iglesia monofisita de Abisinia, donde María ${ }^{11}$ era venerada como en ninguna parte del cristianismo, y donde el Evangelio de la Infancia se recitaba en la predicación del milagro de la Navidad, exactamente como en el Corán. Tor Andrae quiere prevenir el reproche de haber querido hacer de Muhammad un nestoriano.

Muhammad no conoce nada de los sacramentos ni de la mística de Cristo. Tiene mucho del espíritu del Judaísmo en la sequedad de su monoteísmo y en su ausencia de sentimentalidad.

D. J. Sahas, ${ }^{12}$ uno de los mejores conocedores de Juan Damasceno, clave para Muhammad, que vivió muchos años en la corte de los Omeyas, donde desempeñó altos cargos, y que conocía muy bien a Muhammad, a los primitivos musulmanes y que nació poco después de la muerte del profeta, ha resumido su pensamiento sobre el influjo del monacato cristiano en el Islam primitivo, en los siguientes términos:

Giovanni di Damasco egli stesso presbiteo e monaco, deve essere rimasto impressionato dalla regolarità, la puntualità e l'intensità della preghiera musulmana di notte e di giorno, che imitava o era influenzata dalla pratica monastica, e dal rituale che accompagna la vita del musulmano. Il lavarsi prima della preghiera, il digiunare, l'osservare i giorni santi, la circoncisione, l'astensione dal vino e le altre pratiche non sono forse espressione di una vita rituale? Sorprende soltanto che Giovanni di Damasco non facia alcun commento esplicito sulle caratteristiche "monastiche" della vita rituale islamica (prostrazioni, preghiere frequenti di giorno e di notte, abluzioni, digiuni, veglie, eccetera).

Y añade una nota: El profundo influjo ejercido por el monacato oriental sobre Muhammad y los primeros musulmanes, presente en el Islam de todo tiempo, no ha sido hasta ahora adecuadamente considerado. Años antes, Sahas ${ }^{13}$ había publicado una primera valoración del tema. En el presente trabajo se estudia el influjo del monacato sirio sobre el Corán, en varios puntos concretos. El tema ha sido, con ascetas musulmanes, tratado por O. Livne-Kafri. ${ }^{14}$

San Juan Damasceno, que conocía muy bien el Islam y que tenía que conocer a los monjes sirios y palestinos, no relaciona nunca el Islam con el monacato cristiano. En cambio, vincula el Islam -en lo referente a la teología ética- con el maniqueísmo, a propósito del bien y del mal y de su naturaleza. Relaciona al Islam, claramente, con algunas herejías de origen cristiano.

11 Di Salvo 1999, 94, figs. 101, 142-143, 149, 168, 178, 179, 182-185, 191-193, 199, 210 у 216.

12 Sahas 2006; cf. también Le Coz 1992 y BlázQuez 2007b, 529-533.

13 SAHAS 1996.

14 Livne-Kafri 1996; sobre el monacato: Brown 1982; Blázquez 1982; Chitty 1980; Ganivet 1977; BinNs 1994; Rousseau 2000; Brown 1998; HirschFeld 1992; VoöBus 1958-1960. Sobre el monacato sirio, son importantes, además: CANIVEt 1977; PeÑa et alii, 1975, 1980 y 1983; PeÑa 1990; RodríGuez Mediano 2005. Sobre la oración: DE LA FUENTE 2005. Sobre la relaciones de cristianos y musulmanes: FIERRO 2005; MASSOUH 2006; MARTínez 2008, 143-222. Sobre el Oriente arábigo cristiano es importante el prólogo de M. Abumalham a Monferrer 2003, 13-56. 
Juan Damasceno y su discípulo espiritual, Abu Qurrah, tienen la impresión de que el Islam es una síntesis de maniqueísmo, de nestorianismo y de arrianismo. Presentan el Islam como brote de un maniqueísmo dinámico, que surge en el contexto del conflicto teológico e ideológico entre el politeísmo y el monoteísmo judeo-cristiano o entre tendencias filosóficas neoplatónicas y persas, y tendencias monoteísticas, según Sahas. J. Damasceno presenta al Islam como una herejía cristiana.

\section{LOS MONJES DE SIRIA Y EL CORÁN}

Se está bien informado del monacato sirio gracias a la Historia de los monjes sirios de Teodoreto de Cirro, que nació en 399 en Antioquía de Siria, de rica y noble familia. Se desconoce su formación. Se sabe que fue monje. En el año 423 fue consagrado obispo de Cirro, continuando su vida ascética. Siendo obispo se interesó por las obras públicas que beneficiaban a la ciudad. Así, construyó un acueducto, pórticos públicos y dos puentes. Cuidó de los baños públicos y se interesó ante la emperatriz Pulqueria para que se aliviara la presión fiscal. Polemizó contra los herejes de su tiempo: arrianos, marcionitas, apollinaristas y macedonianos. En 427, muerto el patriarca de Constantinopla, Sisinnio, le sucedió Nestorio, que negaba que Cristo fuera Dios y consideraba que a la Virgen no podía llamársela Madre de Dios, Theotokos, sino Christotokos. Teodoreto se opuso a anatematizar a Nestorio y no aprobó su deposición. Hoy día, a Nestorio no se le considera hereje.

Teodoreto fue un prolífero escritor eclesiástico. Publicó obras de carácter exegético, apologístico, dogmático, polémico, histórico, y cartas. Escribió libros contra los principales herejes. Interesa particularmente su Historia de los monjes sirios y la Historia Eclesiástica, en cinco libros, que van del año 323 al 428, escrita esta última entre los años 449 y 450.

La Historia de los monjes sirios consta de 31 capítulos, dedicados cada uno de ellos a contar la vida de un monje, salvo los dos últimos, que están consagrados a dos monjas. En el Prólogo indica el fin que se ha propuesto al escribir esta obra, que no se olvide a los hombres que en un cuerpo mortal y pasible, han demostrado impasibilidad y han emulado la naturaleza incorpórea. Describe los hechos de los monjes contra el enemigo invisible. Más que de una biografía, se trata de alabanzas individuales. Sólo se refiere a monjes del Oriente. Sigue un orden en parte cronológico y en parte geográfico. Escribió la Historia de los monjes sirios hacia el 443, y en todo caso, antes del 449. Su información es esencialmente oral. Los monjes sirios, al igual que los egipcios, eran anacoretas o cenobitas. Una característica de los monjes sirios era pasar la vida subidos a una columna, cargarse de cadenas, ayunar no sólo en la Cuaresma, sino durante todo el año, y las peregrinaciones.

Se usa para el presente trabajo la edición de A. Gallico. ${ }^{15}$ Teodoreto de Cirro escribió las vidas de los siguientes monjes: Santiago, Juliano, Marciano, Eusebio, Público, Simón el Viejo, Palladio, Afraate, Pedro el Gálata, Teodosio, Romano, Zenón, Ma-

15 Gallico, ed., 1996. 
cedonio, Mesima, Acepsima, Marón, Abriamo, Eusebio Salamane, Maris, Santiago, Talassio o Linneo, Juan, Zebina o Policronio, Asclepio, Simeón, Baradate, Talateo, y las mujeres Marana, Cira y Domnina.

\subsection{INFIERNO}

En la Historia de los monjes sirios no se lee ninguna descripción del Infierno; el pensamiento del infierno está mucho más presente en el Corán ${ }^{16}$ (fig. 2). Así, en III:10, se amenaza a los paganos, que serán vencidos y reunidos en el infierno. En IV:59, a los que se apartan del Libro: "en el infierno les bastarán las llamas, y a los que no crean en nuestras aleyas, los quemaremos en un fuego, y cada vez que su piel se quema, les cambiaremos de piel por otra nueva, para que padezcan el castigo".

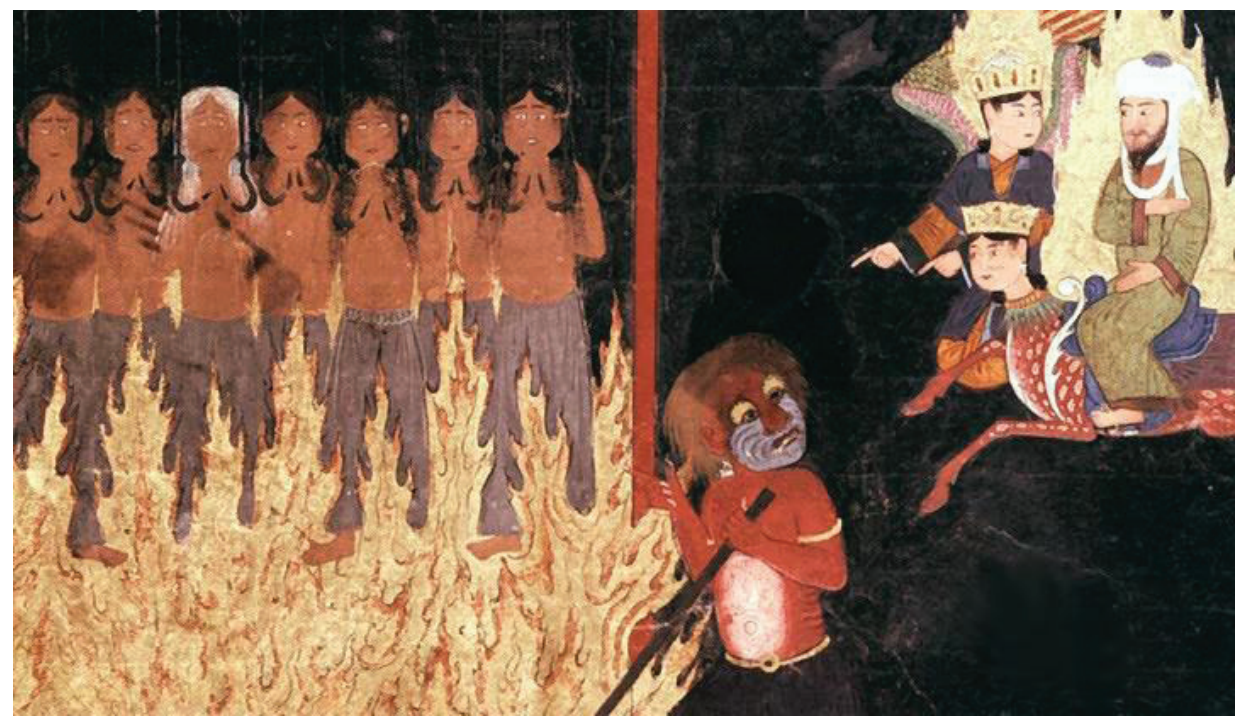

Fig. 2. Representación del infierno musulmán. Manuscrito. Miniatura. Biblioteca Nacional de París.

Se afirma el fuego como castigo del infierno. En VI:128, Dios dice a los genios: "el fuego es vuestra morada, en ella permaneceréis eternamente".

Los que no creen serán reunidos en el infierno (VII:36). En IX:35 se escribe de los judíos: "el día que se les haga fundir en el fuego del infierno, se abrasarán con ellos sus frentes, sus costados y sus dorsos. Los que sean desgraciados estarán en el fuego. En él exhalarán sollozos y suspiros. Permanecerán en él eternamente, mientras duran los cielos y la tierra, al menos que tu Señor no quiera otra cosa".

En XI:108-109, se afirma la eternidad.

16 Asín Palacios 1984; Castillo 1987. 


\subsection{LOS CASTIGOS DEL INFIERNO}

En la Historia de los monjes sirios no se mencionan, al no referirse al Infierno.

En el infierno está el castigo del fuego, pero también sollozos y suspiros. Dios llenará el infierno de genios y de hombres (XI:120). Para los que no han escuchado a su Señor, su refugio será el infierno (XIII:18). El castigo de los incrédulos, es el infierno (XIV:19). Después de la resurrección de los cuerpos: "veréis a los criminales atados a sus hierros. Sus calzones serán de alquitrán y sus rostros estarán cubiertos de fuego" (XIV:50).

En XV:43-44, describe el exterior del infierno: "El infierno es el lugar que a todos les estará prometido. Tiene siete puertas. Ante cada puerta habrá un grupo aislado de infieles".

La recompensa de los que no creyeron será el infierno (XVIII:100). La misma idea se repite en XXXV:33. El XXXVII:62-66, está dedicado todo a la descripción del infierno: "Del fondo del infierno crece un árbol cuyos frutos son como cabezas de demonios. Los condenados comerán de él y se les llenará el vientre. Tendrán como bebida una mezcla de agua hirviendo, y luego volverán a reunirse en el infierno".

Una idea parecida se repite en XXXVIII:57-58: "Los rebeldes tendrán el peor lugar de tortura. En el infierno se asarán en un pésimo lecho. Gustad esto: agua hirviendo y sudando, y otros tormentos variados del mismo género".

Ante los condenados aparecerán las maldades que hayan cometido, y aquello de lo que se burlaban, los rodeará (XXXIX:49). Los que hayan sido infieles, serán conducidos al infierno por grupos. Cuando lleguen a él, se abrirán sus puertas... entrad por las puertas del infierno. Eternamente permanecerán en él (XXXIX:71-72). Se remacha la idea de la eternidad del infierno. "Quienes entren en el fuego, dirán a los guardianes del infierno: Pedid a vuestro Señor que por un momento aligere el tormento" (XL:5253). "El infierno es eterno para los orgullosos" (XL:76).

El fuego será la morada de los impíos (XLI:24), "y su casa para la eternidad, en recompensa de que negaron nuestras aleyas" (XLI:28).

Los que están en el infierno beberán agua hirviente, que les destruirá las entrañas (XLVII:17). Los culpables no creían en la existencia del infierno (LV:43). Insiste en la idea de que, para los que no crean, Dios ha preparado el tormento del fuego (LXVII:6-7). Cuando sean arrojados en él, oirán crepitar el fuego. A los condenados los tratará Dios en el fuego saqar (LXXIV:26). El saqar es uno de los mayores tormentos (LXXIV:38), creado para amonestar a los humanos. "El infierno está cruzado por caminos reales, será el refugio de los rebeldes. En él permanecerán siglos. En él no probarán ni el frío, ni la bebida, sino agua hirviente infecta, como recompensa apropiada a sus obras" (LXXVIII:21-25).

La bajada de Muhammad al infierno, recuerda la de Jesús al Hades (1Pe. 3.19), y la visita al cielo, la Ascensión de Jesús (Lc. 24.50-53). El Libro de la escala de Mahoma fue traducido al castellano por Abraham de Toledo, uno de los traductores judíos de Alfonso X el Sabio. Describe el viaje de Muhammad a Jerusalem, su ascensión a los cielos, y el descenso a los infiernos, acompañado por Gabriel. En el viaje encuentra a Azrael, el ángel de la muerte, al guardián del infierno, a los profetas y a Jesús. Mu- 
hammad visitará los siete estadios del Paraíso y los siete del Infierno. El tema ha sido tratado por el arte musulmán.

Las creencias del infierno entre los monjes sirios no se conocen. En el Corán, al revés, son relativamente numerosas. Admite la eternidad del infierno, el castigo del fuego -al igual que los cristianos- y añade el del agua hirviendo. La creencia en el infierno con fuego se encuentra en el pensamiento de Jesús. En el Nuevo Testamento, el infierno es un lugar de tormento, que recibe diferentes nombres, como gehenna (Mt. 10.28), abismo (Lc. 8.31), horno de fuego (Mt. 13.42), tártaro (2Pe. 2.4) y lago de fuego (Ap. 19.20). Estos nombres no aparecen en el Corán. Se añaden otros tormentos (Mt. 5.22; 8.12; 13.42; 22.13; 25.30; Mc. 9.47; Le. 8.17; Hch. 1.28; Ap. 14.9.11). También en el Corán, además de fuego, se mencionan otros tormentos, como el agua hirviendo. Ni en el Nuevo Testamento, ni en el Corán, ni en los monjes sirios hay una descripción detallada de los diferentes tormentos, según los diversos pecados, como se lee en el Apocalipsis de Pedro, obra que gozó de gran estima, fechada hacia mediados del s. II. En la creencia del infierno cristiano, los condenados están privados de la visión de Dios (Mt. 7.23; 25.6.42; Lc. 3.22-28; 14.24; Ap. 2.11; 20.6; 21.8). Aunque en el Corán esta creencia no se afirme expresamente, se podría suponer.

La idea del infierno está bien presente en los escritores cristianos. El Apocalipsis de Pablo describe los tormentos de los condenados. Menciona el río de fuego, donde sufren las almas de los impíos y pecadores. Describe los tormentos del infierno. Se fecha a mediados del s. III. En los Apocalipsis de la Virgen, María recibe revelaciones sobre los tormentos del infierno, e intercede por los condenados.

Del infierno escribe Justino (Dial. 5.8). Las almas son desgraciadas por su inminente castigo. Cipriano, en su tratado Las buenas obras y la limosna, menciona el fuego del infierno.

La opinión de Orígenes, uno de los grandes colosos del cristianismo primitivo, era que todos los pecadores se salvarán, hasta el mismísimo demonio. Esta teoría tuvo un seguidor en Gregorio de Nisa, que sostiene que las penas del infierno no son eternas, sino temporales. Repetidas veces menciona el fuego inextinguible, la inmortalidad del gusano y una sanción eterna (Orat. cat. 40). Amenaza al pecador con sufrimientos y castigos eternos. Atribuye a estas expresiones el significado de largo período de tiempo. Sigue a Orígenes en la creencia de la restauración universal al final de los tiempos. La apocatástasis no es el final del mundo, sino una fase de tránsito. Para Gregorio de Nisa, la apocatástasis es la conclusión grandiosa y armoniosa de la historia de la salvación (Orat. cat. 26). Teodoro de Mopsuestia, igualmente, opinaba que los castigos de los condenados terminarían algún día. Todas estas ideas son totalmente ajenas a la mentalidad de Muhammad.

\subsection{JUICIO FINAL}

No se habla de él en la Historia de los monjes sirios.

El Corán menciona frecuentemente el Juicio Final. En XXII:2 se lee que el terremoto de la hora del Juicio será algo enorme... todos los hombres estarán aturdidos por el terrible castigo de Dios. Para los que el peso de sus buenas acciones sea ligero, 
ésos serán los que se hayan perdido a sí mismos. En el infierno serán inmortales. El fuego quemará su rostro y en él permanecerán sombríos (XXIII:105-106). Se insiste en la importancia de las buenas obras el día del Juicio (XXVIII.84-90): "Quien venga el día del Juicio con buenas obras tendrá algo mejor que ellas; quien venga con malas obras... quienes hayan obrado con maldad, no se les recompensará sino con lo que hayan hecho".

Más explícita es la descripción en XXXVII:19-33, que dice:

Sólo habrá un grito: entonces ellos verán y dirán: «iAy de vosotros! Éste es el día del Juicio». Éste es el día de la Decisión, al que negabais. ¡Reunid a quienes fueron injustos, a sus esposas y a lo que adoraban prescindiendo de Dios y conducidlos al camino del Infierno! ¡Detenedlos! ¡Van a ser interrogados! ¿Qué os ocurre que no os defendéis? Al contrario; hoy querrían ser sumisos y acercarse unos a otros interrogándose. Dirían: «Vosotros veníais a nosotros por la derecha». Responderían los acusados: «iNo! No erais creyentes. Nosotros no teníamos ningún poder sobre vosotros. ¡No! Vosotros fuisteis gentes rebeldes, y por eso se ha hecho realidad, en contra nuestro la Palabra de nuestro señor. Nosotros vamos a probar el tormento. Os hemos extraviado, cierto, pero también nosotros estábamos extraviados». En ese día ellos estarán asociados en el tormento. Así obramos Nos con los culpables.

Más adelante (XXXIX:69-72) insiste en que juzgará entre los hombres de acuerdo con la verdad; no serán vejados. A cada alma se la recompensará según lo que hace. Quienes hayan sido infieles, serán conducidos al infierno por grupos. Cuando lleguen a él se abrirán sus puertas... La palabra del tormento contra los infieles se cumplirá. Se dará entrada por las puertas del infierno. Eternamente permanecerán en él “¡Cuán mala es la morada de los orgullosos!”. En XLIV:9-10, recomienda el Corán vigilar el día en que el cielo tenga una humareda manifiesta, que envolverá a los hombres. Esto es un tormento pavoroso. El alma va acompañada el día del Juicio (L: 19-25): "Se sopla el cuerno. ¡Este es el día prometido!”; cada alma va al Juicio acompañada de un conductor y un testigo... "Arrojad al infierno a todo incrédulo empedernido, que impide el bien, injusto, escéptico, que ha colocado junto a su Dios otro dios. ¡Arrojadlo al tormento terrible!". La incredulidad es la causa de la condena. Después de la resurrección viene el Juicio (LIV:6-8): "el día en que el pregonero invite a ir a la casa temible, saldrán de su tumba con la vista baja, como si fuesen langostas dispersadas. Tiesos, se dirigirán al pregonero. Los descreídos dirán: «éste es el día difícil»». A los culpables se les conocerá por su fisonomía. Serán cogidos por los pelos y los pies (LV:41). En LXIX:13-18 se dan algunos nuevos datos sobre el día del Juicio:

cuando se sople una sola vez en el Cuerno, cuando la tierra y los montes sean trasladados, destruidos de un solo golpe, en ese día tendrá lugar el acontecimiento, y el cielo se desgarrará, y en ese día carecerá de consistencia. Los ángeles entrarán en sus confines y ocho transportarán, entonces, encima suyo, el trono de su Señor. En ese día seréis expuestos; nada de lo vuestro quedará oculto. 
Al hablar contra los incrédulos, el Corán (LXX:8-19) afirma:

El día en que el cielo sea como cobre fundido y los montes como lana; el día en que un buen amigo no interrogará a otro, aunque se vean; ese día el culpable deseará rescatarse del tormento con sus hijos, con su compañera, con su hermano, con el clan que le da asilo y con todos los que están en la tierra, mientras se salvase. ¡Cuidado! El Infierno llamea arrancando la piel de la cabeza. Llamará a quien haya vuelto atrás y haya vuelto la espalda, haya reunido y capitalizado la riqueza. Cierto, el hombre ha sido creado versátil: cuando le toca la desgracia, es tímido; cuando le toca el bien, es atrevido.

En LXXXI:1-14, se describen los signos externos del día del Juicio:

Cuando el Sol se oscurezca, cuando los astros se empañen, cuando los montes se pongan en marcha, cuando las camellas de diez meses sean abandonadas, cuando las fieras sean reunidas, cuando los mares entren en ebullición, cuando las almas se emparejen, cuando se interrogue a la víctima acerca del pecado que motivó que se la matara, cuando las páginas sean abiertas, cuando el cielo sea destapado, cuando el Infierno sea atizado, cuando el Paraíso sea acercado, toda alma sabrá lo que presenta.

En LXXX:33-39 vuelve el Corán a una idea ya expresada:

Cuando llegue el trompetazo, el día en que el hombre huya de su hermano, de su madre, de su padre, de su amiga y de sus hijos, en ese día a cada hombre sólo le preocupará un asunto; ese día habrá caras radiantes, sonrientes, de buen agüero; en ese día habrá caras cubiertas del polvo: el cieno las cubrirá; esos habrán sido los incrédulos, los libertinos.

En LXXXI:1-12, describe nuevamente los signos que acompañan al Juicio:

Cuando el Sol oscurezca, cuando los astros se empañen, cuando los montes se pongan en marcha, cuando las camellas de diez meses sean abandonadas, cuando las fieras sean reunidas, cuando los mares entren en ebullición, cuando las almas se emparejen, cuando se interrogue a la víctima acerca del pecado que motivó que se la matara, cuando las páginas sean abiertas, cuando el cielo sea destapado, cuando el Infierno sea atizado, cuando el paraíso sea acercado, toda alma sabrá lo que presenta.

Lo mismo, más brevemente, se cuenta en LXXXII: 1-5 y en LXXXIV:1-4. En LXXXVIII:1-6 se describe a los condenados el día del Juicio: “¿Te ha llegado el relato de la que cubre? En ese día verás unos rostros humildes, absortos, agotados, soportando un fuego ardiente; serán escanciados del agua de una fuente ardiendo; no tendrán más comida que euforbio, que no engorda ni aplaca el hambre".

A los signos que acompañarán al día del Juicio, en que cada uno recibirá su merecido, alude brevemente en XCIX:1-8. El día del Juicio, "los hombres estarán como mariposas desorientadas, y los montes como copos de lana cardada" (CI:3-4).

En el Corán, la idea del Juicio ocupa un lugar destacado. Va vinculado a la resurrección, al igual que en Dan. 12.1-3 y en Jn. 5.28. Como en el Nuevo Testamento, 
se señala la solemnidad del Juicio (Mt. 25.31-36; Ap. 20.11-15). Las señales (Mt. 24.20-30; Mc. 13.24; Lc. 21.25). Los signos recuerdan de cerca la descripción del Nuevo Testamento. Una gran diferencia es que, en el Nuevo Testamento, Cristo es el Juez (2Te. 1.7-8; Jn. 5.27-28; Hch. 17.31; 2Tim. 4.1; 1Pe. 4.5). Igualmente es ajena a Muhammad la idea de que el día del Juicio es previo a la instauración del reino mesiánico.

La idea del Juicio Final se encuentra en escritores cristianos. ${ }^{17}$ Aparece en la Carta de Clemente Romano; en la Epistola Apostolorum apócrifa, donde la carne será juzgada junto con el alma y el espíritu; en el Discurso contra los griegos, de Taciano (6-7); en el De principiis de Orígenes; en el De spectaculis (30) de Tertuliano, y en las Divinas Instituciones de Lactancio (7). Teófilo de Alejandría escribió una Homilía sobre el Juicio.

\subsection{RESURRECCIÓN DE LOS MUERTOS}

No está expresada en la Historia de los monjes sirios.

Muhammad se refiere detenidamente a la resurrección en el Corán. En XI:7 pone en boca de Dios: "Seréis resucitados después de muertos".

En XIII.5, el Profeta menciona la resurrección como una creación. En XVI.25 recuerda el día de la resurrección contra los infieles, al igual que en XVI:27 y en XXX:56. En XXXII:10-11, se habla igualmente de la resurrección como una nueva creación, como en XXXIV:7. En L:41 afirma que el pregonero llama a la resurrección y en L:44 que la tierra se abrirá despidiendo a los muertos. En LIV:6 recuerda nuevamente al pregonero, que convoca para algo terrible, como en LIV:8. En LXXV:1 jura Dios por el día de la resurrección. Dios es capaz de juntar los huesos, (LXXV:3), y de recomponer los dedos (LXXV:1). El día de la resurrección la vista se ofuscará, se eclipsará la luna y se reunirán el sol y la luna (LXXV:7-9). En LXXXVI:8, Muhammad sostiene que Dios es capaz de volver a los muertos a la vida. También recoge el Corán, en XLIV:3, que los infieles de la Meca no creían en la resurrección, y que pedían que si era verdad lo que decía, que volvieran sus padres (XLIV:36); lo mismo pedían los infieles (XLV:25). Muhammad estaba totalmente convencido de la resurrección de los muertos, e hizo una apología de la resurrección. En II:259, habla de componer y de cubrir de carne los huesos. Abraham pidió a Dios que le mostrase cómo devolvería la vida a los muertos (II:260). En XXII:5, increpa Dios a los que dudan de la resurrección, ya que ha creado al hombre de tierra, de una gota y de un coágulo de sangre.

En XXII:7 se vuelve a afirmar que Dios resucitará a quienes se encuentren en las sepulturas. En L:14 se vuelve a la idea, ya expresada, de que la resurrección es una nueva creación.

La creencia en la resurrección de los muertos está expresada en el Corán, en los monjes, y en el Nuevo Testamento, también la resurrección de Jesús, que Muhammad acepta (Mt. 28.1-20; Mc. 16.1-20; Lc. 24.1-53; Jn. 20.1-21; Hch. 2.14-36; 3.11-26;

17 Piñero - Gómez Segura 2010. 
4.1-22; 1Cor. 15.1-11). La resurrección de los muertos fue rechazada por los paganos. Los autores cristianos la defendieron y escribieron diferentes tratados, como Tertuliano, que enumera todos los que se oponen a esta creencia, paganos, saduceos y herejes. Metodio, Hipólito, Gregorio de Nisa, Diodoro de Tarso, etc. Es una creencia de origen iranio, documentada en el Yasht (19.11.81), que debió pasar a los judíos a través de las juderías de Babilonia, y de aquí a los judíos de Palestina, y de éstos a cristianos y a musulmanes. La idea del Juicio también es de origen iranio.

\subsection{DEMONOLOGÍA}

Ya en el prólogo (5) afirma Teodoreto (6) que los monjes sirios rechazan con fuerza las tempestades ocasionadas por los dardos del demonio. El demonio se sirve de nuestros miembros como de dardos contra nosotros.

En la vida de Marciano (III.22), se lee que acudió al monje una noble dama de Antioquía, distinguida tanto por su nacimiento como por su riqueza, y le pidió que ayudara a su hija, que estaba combatida por un demonio. El demonio maligno, gritando, abandonó a la joven.

En la vida de Eusebio (V.6) se lee, según el testimonio de Acacio, que luchó contra las insidias del diablo, que no le combatía por las cosas importantes, intentando robarle la castidad y la justicia, armando la concupiscencia, inflamando las pasiones, abrazándole y llenándole de vanidad, metiéndole en la cabeza cosas parecidas a daño del alma. Eusebio guerreó en estas cosas pequeñas. Este párrafo es importante, pues menciona tentaciones carnales, como a Antonio, el fundador del monacato egipcio; si vencía en estas tentaciones, el diablo no le atacaría en cosas importantes y sería derrotado.

Simeón el Viejo, viajando en compañía de muchos hombres nobles al monte Sinaí, juzgó que era un engaño del diablo (VI.7) un hombre que se encontraba en el desierto de Sodoma y levantaba las manos. El viejo le rogó insistentemente que demostrase si tenía naturaleza humana y si no era un demonio engañador (VI.8) como parecía. Al final de la vida de este asceta (VI.13) se menciona que construyó dos monasterios, en los que reunió a atletas de la vida ascética, llegando a ser educador y maestro, enseñando los asaltos del adversario enemigo, el diablo.

Pedro el Gálata (IX.4) purificó con su plegaria y liberó de su diabólica locura a un coribante furioso, que era sacerdote de la diosa Cibeles, famoso por sus danzas frenéticas. En esta misma vida (IX.9) se leen otras menciones del demonio. Un siervo que era cocinero, atormentado por un demonio, fue conducido al monje Pedro el Gálata, que oró y obligó al demonio a manifestar la causa de su poder sobre aquellas criaturas de Dios. Contó que los ascetas de Antioquía tenían gran poder contra los demonios, y que quería conocer por experiencia directa si en realidad los monjes tenían este poder. Se había introducido en el joven, queriendo conocer cómo sería expulsado por los monjes. El demonio huyó y el joven alcanzó nuevamente la libertad.

En la vida de Teodosio (X.6), se cuenta que los jefes de la Iglesia temían que el diablo estimulara en los bárbaros el amor por el dinero, pues habían hecho prisioneros a dos jefes de la Iglesia, a los que dejaron libres por 14.000 monedas de oro. 
Los habitantes de Antioquía se volvieron locos por obra de un maligno demonio, y manifestaron esta locura arremetiendo contra las estatuas del emperador. Llegaron los mejores comandantes del ejército con la orden de arrasar la ciudad. Macedonio (XIII.7) bajó del monte. Trató a los comandantes, que pasaban por la plaza. Los comandantes se bajaron de los caballos. Se dieron la mano. Se abrazaron y lo saludaron.

Es interesante notar que Teodoreto de Cirro atribuye al diablo la decisión tomada por los antioquenos de destruir las estatuas del emperador, actitud que motivó las famosísimas homilías Sobre las estatuas de Juan Crisóstomo, posiblemente la obra cumbre del mejor orador sagrado de la Antigüedad, que también interpretó la funesta decisión de los antioquenos como obra del diablo.

Un noble enfermó. Algunos sostenían que la enfermedad, que consistía en tener un gran deseo de comer, se debía a la acción del demonio. Otros, que era una enfermedad física. La enfermedad consistía en que, comiendo treinta pájaros al día, no saciaba el deseo de comer. Pedía otros. Los parientes acudieron a Macedonio (XIII.9), que vino. Oró. Impuso la mano en el agua. Hizo la señal de la cruz y le ordenó que bebiera. Curó enseguida la enfermedad. Estaba muy extendida la creencia de que las enfermedades eran obras del diablo. Teodoreto recoge en su Historia algunos otros casos de intervención diabólica en los que intervino Macedonio (XIII.10). Una muchacha siria retirada en su casa, de pronto fue presa de un maligno demonio. Su padre acudió al asceta suplicándole que curase a su hija. Macedonio oró y pidió al demonio que se ahuyentase al instante. Afirmaba el diablo que no había penetrado en la muchacha por voluntad propia, sino obligado por la acción de un mago, y que la causa era el amor. El demonio había actuado como ministro de la magia (XIII.11). Indicó el nombre del hombre que había dado a la muchacha la bebida mágica. Se negaba el diablo a descubrir otras cosas; fue obligado a ello. Había incendiado una casa, arruinando árboles y provocando otros daños. Macedonio le obligó a callarse y a alejarse al instante de la joven y de la ciudad. Enseguida huyó. Nuevamente se expresa la creencia de la posesión diabólica: toda clase de males se deben al diablo. El criterio de Macedonio era que en los tribunales no se podía aceptar la muerte basada en pruebas sugeridas por el demonio (XIII.12).

Teodoreto cuenta en la vida de Macedonio (XIII.13) otros casos de posesión diabólica. Una dama muy noble y rica, llamada Astrion, había perdido la cabeza. No reconocía a ningún familiar. No comía ni bebía. Deliraba durante mucho tiempo. Unos decían que había que atribuir la enfermedad al demonio. Los médicos, por el contrario, sostenían que se trataba de una enfermedad mental. La ciencia médica fracasó en la curación. Su esposo, que pertenecía a la curia y que era persona digna de honor, acudió a Macedonio, le expuso la enfermedad de su esposa y le suplicó que la curara. El asceta oró. Acudió a la casa de la dama. Hizo traer un poco de agua; trazó la señal de la cruz y ordenó a la mujer que bebiera. Los médicos defendían que si la dama bebía agua fría, la enfermedad empeoraría. El esposo despidió a los médicos y trajo el agua. La dama, habiéndola bebido, volvió en sí. Se libró para siempre de la enfermedad. Se atribuía al demonio cualquier trastorno corporal.

Marone consagró a Dios un lugar que había sido habitado por los demonios (XVI.1). Estaba muy extendida la creencia de que los demonios habitaban determina- 
dos lugares. La ciudad de Carras era pagana y entregada a la locura de los demonios, según cuenta Teodoreto de Cirro en la vida de Abramo (XVII.5). El asceta se dedicó a convertirla. En la vida de Santiago (XXI.15) se lee que, con encantamientos mágicos de los malos demonios, intentaban combatir al asceta. De noche, vino un demonio gritando. Al impío demonio, en lengua siríaca, le dijo: “¿Por qué tú luchas contra Marción? ¿Por qué jamás has emprendido una lucha contra él? ¿Qué mal te ha hecho? Cesa la guerra. Acaba la enemistad para que aprendas que la paz es un bien. Sábete que, desde hace tiempo, te habría golpeado si no hubiera conocido que te protegen, al mismo tiempo, Santiago, las cenizas de los mártires". Como puntualiza Teodoreto, la herejía de Marción hacía estragos en la ciudad de Cirro. Los demonios protegían a los herejes. Describe el historiador sirio la intervención del demonio, de noche y gritando. El demonio, de noche, imitaba la lamentación de las mujeres (XXI.27). Los demonios provocaban visiones diabólicas. El demonio había revelado a los amigos la visión de los impíos ladrones isaurios viniendo del Oriente, quemando muchas cosas, saqueando. Muchos temían la esclavitud, la prisión, y la presencia de la impiedad y del desorden. Los demonios provocaban falsas visiones. La multitud de demonios esparcidos por todo el mundo motivaban sediciones (XXI.29). Talassio o Limeo arrojaba a los demonios (XXII.3).

En la vida de Taleleo (XXVIII.1) se lee que los demonios que habitaban un templo dedicado a los demonios, es decir, a los ídolos, atormentaban a muchos que pasaban por allí y a los vecinos, no sólo a los hombres, sino también a los asnos, a las mulas, a los bueyes y al ganado. Los demonios no sólo hacían la guerra a seres sin razón, sino que ponían insidias por medio de los animales a los hombres. En este párrafo, los demonios atacan a los animales. Es el único caso de toda la Historia de los monjes sirios.

Juan (XXI.23) sostuvo múltiples ataques de los demonios. Un día vio un hombre desnudo con cara de etíope, que lanzaba fuego por los ojos. Al verlo se llenó de pavor y se puso a orar. No tomó alimento, porque aparecía precisamente en el momento de la comida. Así pasaron siete, ocho, y diez días. Juan continuaba sin comer. Finalmente, despreciando su malvado asalto, se sentó y comió. El demonio no soportó su grandeza de ánimo; le amenazó con golpearle con el bastón. Juan le dijo: "Si el Señor del Universo te ha permitido golpearme, acepto con placer los golpes. Si no te ha sido permitido, no podrás golpearme aunque estés mil veces furioso". Oídas estas palabras, el demonio huyó. Los demonios amenazaban a los ascetas con golpearlos. Los monjes hablaban de los demonios como de cualquier persona.

Los demonios vieron llegar a Taleleo (XXVIII.1). Intentaron asustarlo, pero no pudieron porque su fe le protegía, y la gracia divina combatía con él. Entonces, llenos de locura, rabiando, se retiraron a los árboles plantados en aquel lugar. En aquella colina había muchas higueras y olivos. Se dice -puntualiza Teodoreto- que más de 500 fueron de improviso abatidos por obra de los demonios. Nuevamente se describe a los demonios habitando determinados lugares y actuando sobre la naturaleza vegetal, con el deseo de lanzar daños a los hombres. Habiendo cometido todos estos desmanes, los impíos demonios (XVIII.2) no pudieron asustar al asceta. Buscaron otros procedimientos. De noche, con gemidos y encendiendo luces, intentaban asustarlo y 
turbar su mente. Taleleo se reía de todos sus intentos. Le dejaron y huyeron. Nuevamente se describen las apariciones nocturnas de los demonios a los monjes.

La demonología y la angeología desempeñan un papel importante en el monacato sirio y en el Corán. En la Historia de los monjes sirios no se da ningún nombre de demonios, ni su origen, ni su jerarquía.

En el Corán, el diablo está muy presente. Los coraxies eran gentes rechazadas por no creer en Muhammad (XV:17). Los astros estaban protegidos por los demonios rebeldes (XXXVI:7). En XVIII:48 menciona el libro sagrado el origen de los demonios, que eran ángeles que no se postraron ante Adán cuando Dios se lo ordenó: Se postraron todos menos Iblis, que estaba entre los genios, y fue perverso ante la orden de su Señor. Dios pregunta: “¿tomarás a él y a sus descendientes por protectores prescindiendo de mí? Ellos son vuestros enemigos ¡Qué pésimo cambio es para los injustos!”.

El día del Juicio Final los reunirá el Señor, al igual que a los demonios (XIX:69).

El Señor envió a los demonios contra los infieles, a los que incitan con ardor al mal (XIX.86). El Señor ha adornado el cielo del mundo con candilejas, "que hemos colocado como piedras para lapidar a los demonios. Para éstos, hemos preparado el tormento del fuego" (LXVII:5).

Más frecuentemente, el Corán menciona a Satanás. Quien tiene al demonio como amigo, prescindiendo de Dios, estará en una pesadilla manifiesta. Les promete y les tienta, pero el demonio no promete más que mera seducción. El refugio será el Infierno, y no encontrarán fuera de él sitio (IV:118-120). Se refiere a los incrédulos. En VII:10-17 describe la rebeldía de Iblis:

Os hemos creado; a continuación os hemos formado; enseguida dijimos a los ángeles: «Postraos ante Adán». Todos se postraron, con excepción de Iblis, que no estuvo entre los que se postraban. Dios preguntó: «¿Qué impide que te postres, cuando te lo mando?». Respondió: «Yo soy mejor que él. Me creaste de la luz y a él lo has creado de barro». Dios dijo: «iBaja del Paraíso, pues no es propio que te enorgullezcas en él! ¡Sal! Tú estás entre los desdeñados». Dijo «Déjame esperar hasta el día en que resuciten los muertos». Dios respondió: «Tú estás entre los que esperan». Iblis dijo: «Puesto que me has ofuscado, permaneceré en espera de ellos en tu recto camino, a continuación los alcanzaré asediándolos por delante, por detrás, por la derecha y por la izquierda. No encontrarás, en su mayoría, agradecidos». Dios dijo: «iSal del Paraíso, despreciable, despiadado! Para recompensa de quien te siga de ellos, llenaré el Infierno de todos vosotros!».

Cuando se lee el Corán, Muhammad busca el refugio en Dios contra el demonio lapidado. Éste carece de poder sobre quienes creen en él. Se apoyan en su Señor (XVI.100). Los pródigos son hermanos de los demonios y el demonio es muy ingrato con tu Señor (XVII:29). Más adelante, al referirse contra los infieles de La Meca, afirma el Corán (XVII:55) que Satanás siembra la discordia entre ellos; ciertamente, Satanás es enemigo manifiesto del hombre (XVII:55).

En XVII:63-67, se describe nuevamente la rebelión de Iblis, añadiendo algunos otros detalles: 
Acuérdate de cuando dijimos a los ángeles: «¡Caed postrados ante Adán!». Se postraron todos, excepto Iblis, que dijo: «¿Adoraré a quien has creado del barro?» Añadió: «¿Qué te parece? Si Tú me haces esperar hasta el día de la Resurrección, exterminaré a casi toda la descendencia de éste, a quien honras por encima mío». Dios respondió: «iVete! Tú y quienes de entre ellos te sigan, tendréis el Infierno por recompensa. ¡Recompensa completa! ¡Tienta a quien puedas con tu voz! ¡Ve contra ellos con tu caballería y con tu infantería! ¡Asóciatelos con las riquezas y con los hijos! ¡Promételes! El demonio no les promete más que pura ficción! No tendrá poder sobre mis servidores». Tu Señor basta como protección.

El demonio tentó a Adán en el Paraíso (XX:118). El demonio le tentó: "Dijo: «¡Adán! Te guiaré al árbol de la eternidad y del señorío, que no envejece»”. El Corán recomienda: “¡No sigáis los pasos del demonio, pues quien sigue los pasos del demonio ordena la torpeza y lo reprobable!" (XXIV:21). El demonio espera al hombre traidor (XXIV:31). Al referirse a los apóstatas, escribe (XLVII:27): "Quienes han vuelto atrás después de que les explicara la Dirección, a éstos el demonio los ha seducido y les ha dictado sus acciones". Al aludir a los hipócritas, afirma (LVIII:11) que la confabulación procede del demonio, para entristecer a quienes creen, pero no les perjudica en nada si es con el permiso de Dios. El demonio ha sometido a los hipócritas y a los judíos, y les ha hecho olvidar la instrucción de Dios. Ese es el partido del demonio, o acaso el partido del demonio no es el de los decepcionados.

La última mención a Satanás en el Corán (LIX:16), hablando de los hipócritas que "se parecen al demonio cuando dice al hombre: «Sé descreído»". El demonio anima al hombre a no creer en la revelación de Muhammad.

La demonología del Corán presenta algunas novedades con respecto a la del monacato sirio. Describe el origen del demonio. La tentación del demonio a Adán en el Paraíso. El Corán desconoce las enfermedades humanas causadas por el demonio y su curación mediante hombres santos y las tentaciones demoníacas bajo formas de animales. Coincide el Corán con el monacato en que el demonio tienta a los hombres para perderlos y apartarlos de la revelación de Muhammad. Los demonios están castigados por Dios en los infiernos. La demonología del Corán es menos sobria que la del monacato sirio.

En el Antiguo y el Nuevo Testamento, la demonología ocupa un lugar importante. Se afirma (Ap. 12.7-12), como en el Corán, que fueron arrojados del cielo. Se indica la jerarquía entre ellos (Mt. 12.24.45; 25.41; Mc. 5.9; Lc. 12.7.9), que no aparece ni en el Corán ni en el monacato palestino. Tentó a Adán y a Eva (Ge. 3.1.4.13-14; Ap. 12.9.14-15; 20.2), como se lee en el Corán. Tentó a David y a Job (1Re. 22.19-22; 1Cr. 21.1; 2Cr. 18.18-23; Ib. 1.6.9.12; 2.1.3-4.7; Za. 3.1). Tentó a Jesús (Mt. 4.111; Mc. 1.13; Lc. 4.4-13), pero el Corán no menciona tentaciones de Muhammad. Es adversario perpetuo del reino de Dios (Mt. 13.19; 25.38-39; Mc. 4.15; Lc. 8.12; Jn. 8.44-47; Ef. 6.16; 1Jn. 2.13; 5.18; Ap. 2.9-10.13; 3.9; 9.1-11; 12.3-18; 13.1-18; 16.13-14; 20.7-10). También el demonio se opuso a la predicación de Muhammad. 


\subsection{ANGEOLOGÍA}

Al igual que la demonología, en el monacato sirio y en el Corán, la angeología es conocida.

Ya en el prólogo (2), Teodoreto afirma que los ascetas habían emulado la naturaleza incorpórea, o sea los ángeles.

En la vida de Afrate, escribe el historiador (VII.15), que el monje vivía y cantaba con el coro de los ángeles. Al morir Teodosio (X.8) se decía que emigró al coro de los ángeles. Lo mismo se afirma de Romano (X.5). Zenón (XII.7) fue glorificado, no sólo por los hombres, sino también por los ángeles. En la vida de Simeón (XXVI.12) se recoge la noticia de que los reyes acuñaban monedas con figuras de ángeles. Teodoreto compara la vida de los monjes con la de los ángeles en la biografía de Marciano (III.4).

En el Corán, la angeología ocupa un lugar más destacado que en el monacato sirio y palestino. En II:28 recuerda el Señor a los ángeles: "Pondré en la tierra un vicario". En II:92 se pregunta " ¿Quién será enemigo de Dios, de sus ángeles, de sus enviados, de Gabriel y de Miguel?". Los demonios enseñaron a los hombres la magia negra, y lo que en Babilonia se había revelado a los ángeles Harut y Marut (II.96). Los que no creen, tienen la maldición de Dios y de los ángeles (II.156). "Piadoso es el que cree en Dios, en el Último Día, en los ángeles” (II:172). A qué aspiran los creyentes, "sino a que Dios y los ángeles vengan a ellos en las sombras de las nubes" (II.206). "El signo de la investidura divina será que os vendrá el arca en la que está la Alianza de vuestro Señor y reliquias de lo que dejaron las familias de Moisés y Aarón. Los ángeles la traerán” (II:249). Se refiere a Saúl. “¿No os bastará con que vuestro Señor os auxilie con tres mil ángeles descendiendo del cielo?", se pregunta el Señor con ocasión de la batalla de Ohod o Uhud (III.120). "Dios no os manda que utilicéis a los ángeles y a los profetas como «señores»", dice Muhammad a sus fieles (III.74). "Él es el victorioso por encima de otros siervos, os envía ángeles que guardan la memoria de vuestras acciones" (VI:61). A los creyentes, después de la batalla de Badr, dice: "Acordaos de que pedisteis socorro a vuestro Señor y os respondió: «Yo os auxiliaré con mil ángeles que se sucederán ininterrumpidamente»" (VIII:9). Les recuerda: "Acordaos de cuando vuestro Señor inspiró a los ángeles" (VIII:12). A los de Ohod les recuerda: "iSi pudierais ver el momento en que los ángeles llaman a quienes no creen! Los golpean en la faz y en las espaldas, diciendo: «iGustad el tormento de la incineración!»" (VIII.52). En XV:28 dice el Señor: "Acuérdate de cuando dijo tu Señor a los ángeles: «Estoy creando un ser humano a partir del barro»". Los ángeles llamarán a los que fueron injustos (XVI:30) y a los buenos (XVI:34). El Señor no ha tomado a los ángeles por mujeres (XVII:42). Los incrédulos dijeron: "El Clemente ha adoptado a los ángeles por hijos" (XXI.26). "Son sus servidores honrados. No le preceden al hablar y ejecutan su orden" (XXI:27). "Dios escoge entre los ángeles y los hombres enviados" (XXII:74). "El ángel de la Muerte, al que se ha encargado de vosotros, os llamará" (XXXII:11). El día en que el Señor "reúna a todos los impíos, preguntará a los ángeles: «¿Éstos os adoraban a vosotros?»" (XXXIV.40). Los ángeles son los mensajeros del Creador y tienen dos, tres y cuatro pares de alas 
(XXXV:1). El Señor pregunta si acaso ha creado ángeles, hombres, como se atestigua (XXXVII:150).

En XXXVIII:67-85, se refiere a la revelación de Lucifer en los siguientes términos:

Di: «Esto es un relato serio, del cual os apartáis». No tengo conocimiento de lo que ocurrió en el Consejo Altísimo, cuando sus miembros se querellaron. No se me ha inspirado, sino que soy un amonestador explícito. Recuerda cuando tu Señor dijo a los ángeles: "Yo voy a crear un ser humano de barro. Cuando le haya modelado y haya insuflado en él parte de mi Espíritu, ¡caed, ante él, postrados!». Todos los ángeles se postraron, excepto Iblis. Éste se enorgulleció y estuvo entre los infieles. Dios preguntó: « ¡Iblis! ¿Qué te ha impedido postrarte ante lo que he creado con mis dos manos? ¿Te has enorgullecido o estás entre los soberbios?». Respondió: «Yo soy mejor que él. A mí me creaste del fuego y a él le has creado de barro». Dios exclamó: «¡Sal del cielo! ¡Tú eres lapidable! ¡Caiga sobre ti mi maldición, incesante, hasta el día del Juicio!». Satanás dijo: «¡Señor mío! ¡Concédeme un plazo hasta el día en que sean resucitados!». Dios contestó: «Tú estás entre los que esperarán hasta el día del instante determinado». Satanás exclamó: «¡Por tu poder! ¡Seduciré a todos los humanos, con excepción, entre ellos, de tus servidores puros». Dios dijo: «¡Verdad! ¡Digo que llenaré el Infierno contigo y con los que te sigan!». Di: «No os pido por ello salario. No estoy entre los obsesionados. Esto es una Instrucción para los mundos. Cierto, conoceréis su anuncio después de un plazo».

El día del Juicio Final, los ángeles rodearán el trono, cantando las alabanzas de su Señor (XXXIX:75). En XL:7-9, se cuenta la intercesión de los ángeles:

Quienes llevan el trono y están a su alrededor cantan la loa de su Señor, creen en Él y piden perdón para quienes creen, diciendo: «iSeñor nuestro! Abarcan toda cosa con tu misericordia y con tu sabiduría ¡Perdona a quienes se han arrepentido y han seguido tu senda! ¡Guárdalos del tormento del Infierno! ¡Señor nuestro! ¡Hazlos entrar en los jardines del Edén que les has prometido! ¡Haz entrar también a sus padres, a sus esposas y a sus descendientes! Tú, Tú eres el Poderoso, el Sabio. ¡Guárdalos de las maldades! Aquel a quien preserves de las maldades, en ese día Tú le tendrás misericordia. Ése es el éxito mayor».

En XLII:3, "los ángeles cantan la alabanza de su Señor e imploran perdón para quienes están en la tierra". Los idólatras "han atribuido el sexo femenino a los ángeles, que son servidores del Clemente" (XLIII:18). El día del Juicio Final, "los ángeles estarán en sus confines, y ocho transportarán, entonces, encima suyo, el trono del Señor" (LXIX:17). Los ángeles son los guardianes del fuego, o sea, del Infierno (LXXIV:31). En la última mención del Corán (XCVI:18) se alude a los arcángeles.

Monjes y musulmanes creen en la existencia de los ángeles, que son servidores de Dios. A los monjes se les aparecen en sueños. En el Corán no; en él se describe varias veces la caída de los ángeles y su castigo, y en el monacato sirio, no. En el Corán, los ángeles rodean el trono del Señor, en el monacato, no. Las biografías de los monjes no describen a los ángeles. El Corán afirma que tienen dos, tres o cuatro pares de alas. 
El Corán sostiene que los ángeles no son de sexo femenino. Los monjes no plantean este tema. Los monjes sirios no tenían esta creencia. En el Corán, los ángeles transportan las almas de los justos al cielo. El Corán menciona a Gabriel, a Miguel y a los ángeles de Babilonia, Harut y Marut. En el Corán, el Señor envía a los ángeles a socorrer a sus fieles en la batalla. En el Corán, los ángeles son los mensajeros. La opinión del monacato sobre los ángeles es mucho más corta que en el Corán, que repite ideas.

En las Sagradas Escrituras, judías y cristianas, los ángeles están ante Dios (1Re. 22.19; Is. 6.2-3; Da. 7.10; Mt. 18.10; Lc. 12.48; Ap. 5.11; 7.11). Tienen diferentes ministerios cerca de los hombres (Ge. 19.7; 28.12; 1Re. 19.5; Jb. 5.1; Sal. 33.8; 90.11; 2Mac. 10.29; Lc. 15.10; Hch. 5.19; Hab. 1.13-14; Ap. 5.8; 8.3-4). Hay diferentes órdenes de los ángeles (Co. 1.16; Ef. 1.21; 1Te. 4.15; Jds. 9). Miguel, Daniel y Rafael son citados (To. 12.15; Da. 8.16; 9.21; 10.13.21; 12.1; Lc. 1.19.26; Jds. 9; Ap. 12.7). Algunas ideas del Corán sobre los ángeles están muy próximas a las de las Sagradas Escrituras judías y cristianas.

\subsection{CIELO}

En la Historia de los monjes sirios no se describe el cielo. Tan sólo se menciona el coro de los ángeles en el cielo, en los textos ya mencionados.

El Corán es mucho más explícito. En II:23 se afirma (fig. 3):

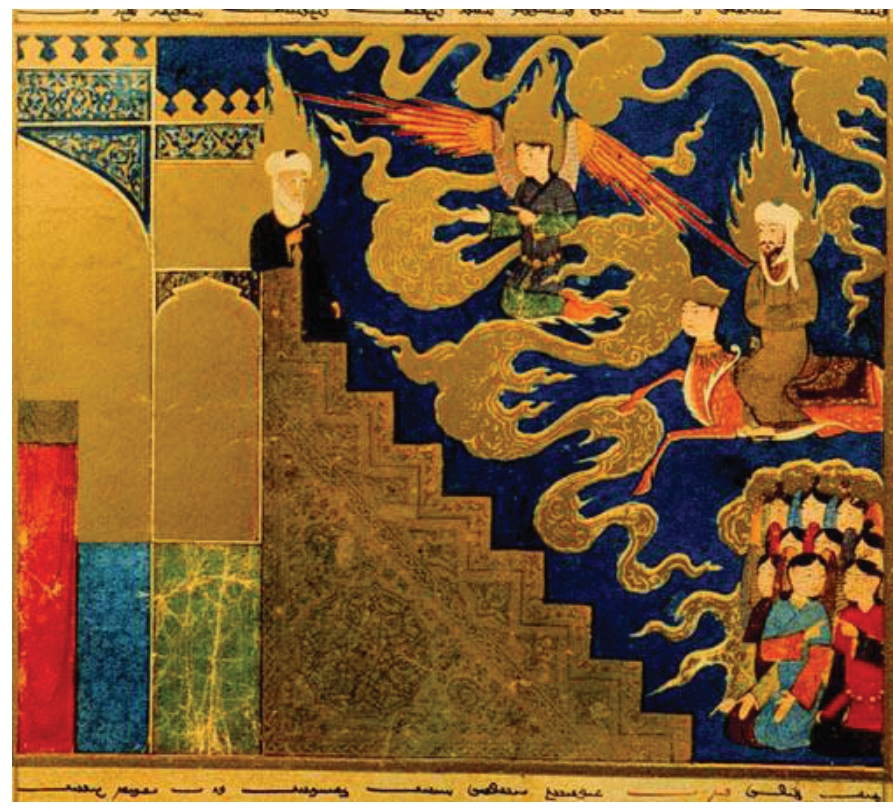

Fig. 3. Representación del cielo musulmán. Manuscrito. Miniatura. Biblioteca Nacional de París. 
Albricia a quienes creen y hacen buenas obras, que tendrán unos jardines en que corren los ríos por debajo. Cada vez que se alimenten de sus frutos dirán: «Esto es lo que se nos dio de alimento anteriormente», pues tendrán la apariencia de los de esta vida. Tendrán esposas puras, y ellos, en los jardines, serán inmortales.

Estas ideas se van a repetir frecuentemente, y a ampliarse, como en III.13: "Quienes son piadosos tendrán, junto a su Señor, jardines en que, por debajo, correrán ríos; en ellos estarán eternamente, teniendo esposas puras y la satisfacción de Dios". Para los nómadas del desierto, esta descripción del Paraíso es ideal. La misma descripción se encuentra en IV:60 y en X:9. En XIII:23-24 se afirma que los piadosos

tendrán la última morada, entrarán en los Jardines de Edén, donde también entrarán quienes, de entre sus antepasados, sus esposas o su descendencia, hayan sido piadosos. Los ángeles se dirigirán a ellos por cada puerta, diciendo: «iLa paz sea con vosotros, porque tuvisteis paciencia! ¡Cuán hermosa es la última morada!».

En este párrafo se afirma que los ángeles esperan a los justos y que el Paraíso tiene diferentes puertas. En XIX:61-64, añade el Corán algunos datos nuevos:

Esos entrarán en el Paraíso y no serán vejados en nada. Tendrán los jardines del Edén, que, sin darles pruebas, el Clemente prometió a sus servidores. Ésa es su promesa venidera. En ellos no oirán más palabras que «paz», en ellos tendrán su alimento mañana y tarde. Ese paraíso es el que hemos dado en herencia a nuestros servidores, a aquellos que fueron piadosos.

Una descripción más detallada del Paraíso se encuentra en XXXVII:37-49:

Se exceptúan los servidores devotos de Dios. Éstos tendrán un sustento determinado de frutos; ellos serán honrados en unos jardines de ensueño; estarán sentados sobre estrados enfrentados. Entre ellos circulará en ruedo la copa llena de agua corriente, blanca, dulce al paladar de los bebedores; no contendrá embriaguez ni se embriagarán de ella. Tendrán vírgenes de mirada recatada, con ojos como huevos de avestruz semiocultos.

En XXXVIII:49-53 se insiste en la misma idea: "Los piadosos tendrán un hermoso lugar de retorno: los Jardines del Edén tendrán abiertas sus puertas; recostados, en ellos pedirán múltiples frutos y bebida, y junto a ellos estarán las vírgenes de mirada recatada, de su misma edad. «Esto es lo que se os prometió para el día de la Cuenta»". En XXXIX:21-22 se promete a los fieles que tendrán salones, encima de los cuales habrá otros salones; a sus pies correrán los ríos. Es la primera vez que se habla de los salones en el Paraíso. Algunos datos nuevos se añaden a la descripción del Paraíso en XLIII:71-73:

¡Entrad en el Paraíso! Vosotros y vuestras esposas seréis honrados. Entre ellos se hará circular platos y tazones de oro; en ellos habrá lo que desean las almas, y place a los ojos. Vosotros permaneceréis allí eternamente. Este es el Jardín que habéis heredado en recompensa de lo que habéis hecho. En él tendréis frutos abundantes, que comeréis. 
En XLVII:16-17, se dice:

Imagen del Paraíso que se ha prometido a los piadosos. En él habrá ríos de agua incorrupta; ríos de leche de composición inalterable; ríos de vino, que serán delicia de los bebedores, y ríos de miel limpia. Los creyentes tendrán toda clase de frutos, y perdón procedente de su Señor. ¿Quien esté en este jardín de ensueño será comparable a quien permanezca eternamente en el fuego? Beberán agua hirviente que les destruirá las entrañas.

Por vez primera se menciona el vino y la miel en el Paraíso. Una descripción minuciosa del Paraíso se lee en LV:46-78:

Quien haya temido el emplazamiento de su Señor, tendrá dos jardines - ¿qué dones de vuestro Señor negaréis?- frondosos. ¿Qué dones de vuestro Señor negaréis? En ellos habrá dos fuentes de agua corriente. ¿Qué dones de vuestro Señor negaréis? En ambos habrá, de toda clase de frutos, dos especies. ¿Qué dones de vuestro Señor negaréis? Los bienaventurados estarán reclinados sobre tapices cuyo reverso será de brocado; la cosecha de ambos jardines será inmediata. ¿Qué dones de vuestro Señor negaréis? En ambos habrá mujeres de mirada recatada; antes de ellos no las habrá tocado ni hombre ni demonio. ¿Qué dones de vuestro Señor negaréis? Ellas serán como rubíes y coral. ¿Qué dones de vuestro Señor negaréis? La recompensa del bien es el bien. ¿Qué dones de vuestro Señor negaréis? Prescindiendo de ambos habrá dos jardines - ¿qué dones de vuestro Señor negaréis?- oscurísimos por lo frondoso de su vegetación. ¿Qué dones de vuestro Señor negaréis? En ellos habrá dos fuentes abundantes. ¿Qué dones de vuestro Señor negaréis? En ambos habrá frutos, palmerales y granados. ¿Qué dones de vuestro Señor negaréis? En ambos habrá vírgenes excelentes, hermosas - ¿qué dones de vuestro Señor negaréis?- huríes enclaustradas en pabellones. ¿Qué dones de vuestro Señor negaréis? Antes de ellos no las habrá tocado ni hombre ni demonio. ¿Qué dones de vuestro Señor negaréis? Los bienaventurados estarán reclinados sobre cojines verdes y hermosos abqarí. ¿Qué dones de vuestro Señor negaréis? ¡Bendito sea el nombre de tu Señor, que posee la majestad y la nobleza!

En esta descripción se mencionan, como novedad del Paraíso, dos fuentes de agua corriente, toda clase de frutos, estar recostados en tapices cuyo reverso será de brocado, la cosecha inmediata de ambos Jardines, mujeres vírgenes como rubíes y coral, jardines oscurísimos por lo frondoso de su vegetación, palmerales y granados, huríes enclaustradas en pabellones, estar recostadas en cojines verdes y hermosos abqarí.

En LVI:10-39 se añaden nuevos datos:

Los precursores, ésos son los allegados a Dios en los jardines de ensueño. Serán multitud de antiguos creyentes y pocos de los contemporáneos. En estrados incrustados de oro y pedrerías se reclinarán enfrentados. Entre ellos circularán garzones inmortales, con cráteras, aguamaniles y vasos con bebidas refrescantes que no les amodorrarán ni les embriagarán. Tendrán las frutas que escojan y la carne de pájaros que deseen; mujeres de ojos rasgados, parecidos a la perla semioculta, en recompensa de lo que hayan hecho. En ellos no oirán ruido ni incitación al pecado, sino el dicho: «¡Paz! ¡Paz!». Los compañeros de la derecha, ique son los compañeros de la felicidad!, estarán entre azufaifos sin espi- 
nas, entre acacias alineadas, sombras extendidas, agua corriente y abundantes frutos que no estarán cortados ni prohibidos. Estarán echados sobre tapices elevados. Las huríes, a las que hemos formado, a las que mantenemos vírgenes, coquetas, de la misma edad, pertenecerán a los compañeros de la derecha, un grupo de los antiguos, y un grupo de los contemporáneos.

Se mencionan varias novedades: estrados incrustados de oro y pedrerías, donde los fieles se reclinarán uno delante de otro; jóvenes inmortales que circulan entre ellos con cráteras, aguamaniles y vasos con bebidas refrescantes, que no les amodorrarán; frutas y pájaros que deseen, mujeres de ojos rasgados parecidas a perlas ocultas; ausencia de ruido. En LVII:21 se afirma que la anchura del Paraíso es como la del cielo y de la tierra. La última descripción del Paraíso se lee en el Corán, LXXVI:11-22. Es como sigue:

Dios les ha puesto a salvo del daño de aquel día y les ha dado juventud y alegría. Su recompensa, por haber sido constantes, es un Paraíso y vestidos de seda; en el Paraíso estarán reclinados en sofás; desde él no verán el Sol, ni notarán su ardor. Cerca de ellos estarán árboles umbrosos cuyos frutos se inclinarán hasta el suelo. Entre ellos circularán vasos de plata y cráteras que serán de cristal, de cristal de plata de gran valor. En él se escanciará un vaso en cuya mezcla habrá jengibre. Habrá una fuente que se llamará Salsabil; entre ellos circularán donceles inmortales: cuando los veas creerás que son perlas desgranadas. Cuando mires en seguida verás los jardines y la gran realeza. Vestirán trajes verdes de raso y brocado, se les adornará con brazaletes de plata, y su Señor les escanciará una bebida pura. Se les dirá: «Esto es para vosotros, en recompensa. Vuestro esfuerzo ha quedado recompensado».

Se añaden datos nuevos, como que los fieles vestirán trajes de seda, que estarán reclinados en sofás. No habrá calor. Los árboles producirán unos frutos que se inclinarán hasta el suelo. Los vasos y cráteras serán de cristal. El jengibre será la bebida. Se vestirán trajes verdes de raso y de brocado. Se les adornará con brazaletes de plata. Su Señor les escanciará una bebida pura.

Se ha acusado a Muhammad de tener una concepción no espiritual, sino material, del Paraíso, ${ }^{18}$ pero era la única, muy posiblemente, que las gentes que habitaban el desierto de Arabia podían imaginar y aceptar. Una concepción espiritual del Paraíso sería inimaginable para ellos. Las huríes tienen un paralelo en los himnos del Paraíso de Efrén el Sirio, que es el único texto cristiano con placeres sexuales en el cielo.

Los Himnos del Paraíso (103-104) de Efrén (306-373), que era un asceta, son las piezas fundamentales de la vida en la iglesia siria, en los que se mencionan también placeres carnales:

Yo ví en las mansiones de los justos y a ellos mismos chorreando ungüentos, exhalando perfumes, enguirnaldados de flores, coronados de frutas... Cuando se recuestan a las mesas, los árboles dan sombras en el aire. Las flores brotan entre ellos. Las frutas sobre ellos. Su techo es de frutas. Sus alfombras flores... Rápidos vientos delante de ellos están dispuestos a servirles. El uno exhala saciedad, el otro hace fluir bebidas.

18 Monferrer 2005; Oliva 1996. 
Un hálito de viento está lleno de óleo, lleno de ungüento. ¡Quién vio jamás servir a los vientos! ¡O soplos de viento que se pueden comer y beber! Aquí dan los vientos de un modo espiritual a seres espirituales sustento. Es un festín y sin esfuerzo y en que las manos no se fatigan. ¡Piensa, oh, viejo, en el Paraíso! Cuando su aliento te refresca, que un día y sus perfumes te rejuvenezcan, tus manchas desaparecerán en la belleza que te rodea. Sus mejillas que estaban llenas de arrugas se han vuelto hermosas y radiantes. Es un símbolo místico de cómo ha de rejuvenecer la vejez en el Paraíso... A quien en la tierra se ha abstenido del vino, a ese anhelan las cepas del Paraíso. Cada una le alarga una uva colgada. Y si alguien ha vivido casto, le reciben las mujeres en su puro seno, porque como monje no cayó en el seno ni en el lecho del amor terreno.

Es probable que la visión del Paraíso de Muhammad responda a la de Efrén, muy leído por los monjes.

Los mosaicos de la Mezquita de Damasco representan el Paraíso musulmán. ${ }^{19}$ Los investigadores que han estudiado estos mosaicos los han interpretado como una representación del Paraíso musulmán, como E. Börsch-Supan, B. Finstess, O. Grabar y J. Balty. Los cristianos, después podían aceptar con facilidad esta imagen. Los artistas proceden, probablemente, de Constantinopla.

Posiblemente en esta descripción influyó la descripción del Paraíso terrenal (Ge. 2.8-25) y otros textos de las Sagradas Escrituras hebreas y cristianas. Es un lugar muy ameno (Ca. 4.13; Ez. 28.13), y el lugar de los bienaventurados (Lc. 23.48; 2Cor. 12.13).

La concepción del Corán del Paraíso es desconocida en los autores cristianos. Orígenes, una de las mejores cabezas del cristianismo primitivo y el más culto, en su Exhortación al martirio (30) afirma que los confesores de la fe van al Paraíso. Tertuliano (De anima, 55) escribe que la única llave que abre las puertas del Paraíso es la sangre de su propia vida. En su tratado De Paraíso sostiene que todas las almas permanecen en el Hades menos las de los mártires. Permanecen allí hasta la venida del Señor ( $a d v$. Marc. 5.12). El autor, posiblemente Tertuliano, tratando del martirio de Perpetua y Felícitas, mártires africanas del 202, refiere que la protagonista, en la visión del Paraíso, sólo vio a sus compañeros mártires. Cipriano, en el De inmortalitate 26, menciona el Paraíso como el domicilio eterno de los cristianos, donde se encuentran los seres queridos, padres, hermanos y allegados, y los patriarcas.

\subsection{ORACIÓN}

Los monjes sirios, al igual que los musulmanes, oraban continuamente. En este punto, los musulmanes son idénticos a los monjes.

Juliano (II.5) hacía oración todo el día, sin interrupción de la mañana a la tarde. Cuando Juliano, llamado por los cristianos El Apóstata (360-363), planeó la expedición contra los persas, amenazó a los cristianos con destruirlos. Juliano elevó a Dios

19 Los mosaicos de la Mezquita de Damasco como representación del Paraíso musulmán, en HeLlenKerper SAlies 1988, 295-313; el volumen en que se incluye este trabajo es fundamental para Siria en la Tarda Antigüedad. 
(II.14) continuas oraciones y oyó una voz que le comunicaba que el impío y abominable emperador había sido asesinado. No dejó de orar. Terminó y cambió la plegaria en cánticos. Entonó un himno de gracias al Salvador de los suyos.

Marciano, a la salmodia seguía la plegaria, y a la plegaria la salmodia, y, a una y otra, de nuevo la lectura de las Sagradas Escrituras; es decir, oraba continuamente.

Eusebio (IV.5) exhortaba a dialogar siempre con Dios, a no dejar un momento sin orar, a celebrar continuamente la liturgia establecida. Oraba al Señor durante el día. $\mathrm{Su}$ casa era casa de oración. No quería abandonarla. Se cuenta que así vivió más de 40 años (IV.6). Los ascetas que habían vivido más de 90 años hacían súplica a Dios durante todo el día y toda la noche, celebrando la sagrada liturgia (IV.12). Eusebio, durante la mayor parte del día y de la noche, dirigía la liturgia de la plegaria a Dios, de pie o de rodillas.

Publio (V.2), igualmente, a la plegaria seguía la salmodia, y a la salmodia la plegaria, y ambas a la lectura de las Sagradas Escrituras. Simeón el Viejo participaba en la salmodia y en la plegaria con otros, y al fin de la liturgia los despidió, maravillados de lo que habían visto, a un león que apareció, marcharse a una señal de Simeón. Volvió con un manojo de dátiles; se marchó lejos y se durmió (VI.10).

Palladio (VII.1) se había recluido en una celda, en una aldea grandísima y muy poblada llamada Imma, que distaba $40 \mathrm{~km}$ de Antioquía, y se pasaba la vida ayunando, en vigilias y en plegarias continuas. Afraate, Flaviano y Diodoro cantaban sin interrupción el canto al Señor, en los montes, en la llanura, en la ciudad, a las afueras, en las casas y en la playa (VIII.6). La ocasión era que los escitas y otros bárbaros saqueaban violentamente toda la Tracia, desde Istro hasta la Propóntide (VIII.5), mientras el emperador empleaba las armas contra los compatriotas, contra los súbditos y contra el que era famoso por su piedad religiosa. Teodosio (X.29), con la continua plegaria y con el continuo canto de himnos, aplacaba la concupiscencia, la ira, el orgullo y las otras fieras salvajes de su ánima. La oración aplacaba, pues, todos los malos deseos. Abramo (XVII.2) se marchó a vivir a una aldea del Líbano que era pagana, disfrazado de mercader. Alquiló una casa y celebró en ella la liturgia. Los habitantes de la aldea oyeron la salmodia. La salmodia y la liturgia eran parte esencial de la religiosidad de los ascetas. Abramo (XVII.5), consagrado obispo de Carras, de noche cantaba cuarenta himnos completos a coro, alternando. De obispo seguía un ascetismo riguroso.

Los ascetas solían pasar la noche cantando himnos y dedicados a la liturgia. Maris (XX.2) pasaba mucho tiempo cantando salmos. Talasio (XXII.7) exhortaba a la gente a cantar himnos. Santiago (XXI.13), con ocasión de una nevada que cayó durante tres noches y tres días, oraba a Dios tirado en tierra. Policronio (XXIV.7), por sus plegarias, obró muchos milagros.

\subsection{PURIFICACIÓN}

En el Corán, II.43, se manda lavarse antes de la oración. Los monjes sirios no practicaban ninguna ablución antes de la oración, ni nunca. 


\subsection{MODO DE ORAR}

En la biografía de Juliano (II.5) se describe la postura de orar, haciendo genuflexiones, de pie, o postrándose en tierra. La misma postura se indica en la vida de Eusebio (IV.12), de pie o de rodillas. En la vida de Baradate (XXVII.3), el asceta oraba de pie, levantando las manos al cielo. Los musulmanes oran del mismo modo hasta el día de hoy, al igual que la iglesia cristiana de Abisinia, que es de origen sirio.

En el Corán, las menciones a la oración son numerosas. A Dios se le puede orar en cualquier lugar, pues a Él pertenecen el Oriente y el Occidente (II:109). Lo mismo se afirma en II:136-140. En II:286 se pone un ejemplo de oración:

¡Señor nuestro!: No nos reprendas si olvidamos o faltamos. ¡Señor nuestro!: No nos agobies con un fardo semejante al que cargaste sobre quienes nos precedieron. ¡Señor nuestro!: No nos cargues con lo que no tenemos fuerzas para soportar. ¡Borra nuestras faltas! ¡Perdónanos! ¡Ten misericordia de nosotros! Tú eres nuestro Señor; auxílianos contra la gente infiel.

El Corán recoge otros ejemplos de oración. Así, en III:188-192:

Imploran a Dios y meditan acerca de la creación de los cielos y de la tierra, diciendo: Señor nuestro: No has creado todo esto en vano. ¡Gloria a Ti! ¡Presérvanos del castigo del fuego! ¡Señor nuestro! A quien Tú introduces en el fuego, le cubres de oprobio. Los injustos no tienen defensores. ¡Señor nuestro! Hemos oído a un hombre, llamando a la fe, diciendo: «¡Creed en vuestro Señor!», y hemos creído. ¡Señor nuestro!: Perdónanos nuestros pecados, bórranos nuestras malas acciones y llámanos a morir con los piadosos. ¡Señor nuestro! Danos lo que nos has prometido por tus enviados y no nos avergüences el día de la Resurrección. ¡Tú no cambias la promesa!

Se legisla (IV:46) sobre los requisitos previos a la oración:

¡Oh, los que creéis! No os acerquéis a la oración si estáis ebrios, hasta que sepáis lo que decís; ni impuros, a menos de que estéis en camino, hasta que os lavéis; si estuvieseis enfermos o de viaje, si viniese uno de vosotros de hacer sus necesidades, o habéis tocado a las mujeres y no encontráis aguas, frotaos con polvo bueno -arena- y lavaos vuestros rostros y manos. Dios es absolvente, indulgente.

En el monacato no se menciona ningún requisito.

Se debe orar en el momento de peligro (IV:102-104):

Cuando recorréis la tierra no cometéis falta al abreviar la plegaria si teméis que os ataquen quienes no creen. Los infieles son vuestro enemigo manifiesto. ¡Profeta!, cuando estés entre los creyentes y los dirijas en la plegaria, permanezca una parte de ellos junto a ti y coja sus armas. Cuando los que rezan se prosternen, que estén detrás de ellos. Luego, venga la otra parte que no ha rezado y ore contigo. Los que ya han rezado, pónganse en guardia y cojan sus armas (...). Cuando cumpláis la plegaria, invocad a Dios en pie, sentados o tumbados. Cuando estéis seguros, cumplid la plegaria tal como está mandado. La plegaria es, para los creyentes, un contrato a plazo fijo. 
En el monacato no se leen plegarias antes de los ataques.

Antes de la oración había que hacer unas abluciones (V:8-9):

\begin{abstract}
¡Oh, los que creéis! Cuando os dispongáis a hacer la plegaria, lavad vuestras caras y vuestras manos hasta los codos. Pasad la mano por la cabeza y por los pies hasta los tobillos. Si estáis impuros, purificaos; si estáis enfermos, en viaje o viniese uno de vosotros del retrete, o hubieseis tocado a las mujeres y no encontraseis agua, frotaos con polvo bueno -arena- y lavaos vuestros rostros y vuestras manos. Dios no quiere poneros en dificultad, pero desea que os purifiquéis y llevar a término sus bondades para con vosotros. Tal vez seáis agradecidos.
\end{abstract}

Estas abluciones antes de las plegarias no las hacían los monjes.

Las abluciones en el Corán son de influjo judío. En las Sagradas Escrituras, los sacerdotes debían bañarse en el momento de recibir el sacerdocio. Antes de entrar en la tienda de la Reunión, se lavaban pies y manos (Ex. 29.4; 30.19-21; 40.30-32; Lc. 8-6). Los levitas eran asperjados antes de ser consagrados (Nu. 8.6-7). Al concederse la Alianza en el Sinaí, a los israelitas se les ordenó lavarse los vestidos (Ex. 19.10-11). Abluciones se hacían antes de las comidas (Jn. 2.4). Los que tocaban los cadáveres se purificaban con agua (Nu. 19.1-10;17-22).

La plegaria había que hacerla en el límite del día y en distintas partes de la noche (XI:116). Esto tampoco lo cumplían los monjes, que oraban a cualquier hora del día y de la noche. Lo mismo se prescribe en XVII:80-81: "Cumple la oración desde la caída del sol hasta la entrada de la noche (...) Durante la noche permanece en vela rezando: te sirve como obra superrogatoria". Los monjes oraban toda la noche. La plegaria impide la torpeza y lo reprobable (XXIX:38-44). En L:38-39: “¡Canta el loor de tu Señor antes de la salida del Sol y después del ocaso! Durante parte de la noche, después de postergarte, lóale". La oración de los monjes debía ser de alabanza, principalmente, cuando se recitaban salmos.

Los monjes y los musulmanes eran hombres de oración continua, día y noche. Es un aspecto que acerca la religiosidad islámica al monacato.

En las Sagradas Escrituras judías y cristianas, se recomienda, igualmente, orar sin interrupción (Sal. 118.62; Mt. 7.7; Lc. 11.9; 8.1, Hch. 10.2; Ef. 6.18; 1Te. 3.10; 5.17; 1Tim. 1.3). Jesús oraba frecuentemente (Mt. 14.23; 22.45; Heb. 5.7.10).

En las Sagradas Escrituras judías, el agua se utilizaba para purificarse $(\mathrm{Nu}$. 8.7;10.1-10.20) desde los orígenes de la Historia de Israel. Los israelitas lavaron sus vestiduras antes de recibir la alianza del Sinaí (Ex. 19.10-11). Todo el que toque un objeto impuro debe lavarse (Le. 11.32). Los sacerdotes se bañaban en el momento de recibir el sacerdocio; se lavaban manos y pies antes de penetrar en la tienda de la Reunión (Ex. 29.4; 4.30-32; Le. 8.6). A los levitas se les asperjaba antes de su consagración ( $\mathrm{Nu}$. 8.6-7). El israelita que tocaba un cadáver, debía purificarse con el agua (Nu. 19.1-10; 17.1-22). Los fariseos y los levitas, siguiendo las tradiciones de los antiguos, se lavaban las manos antes de comer (Mc. 7.1-6; Mc. 15.2). Jesús es más liberal en la aplicación de la ley.

En el templo de Salomón en Jerusalem, estaba el mar de bronce, gigantesco recipiente sostenido por 12 toros, que simbolizaba el Océano y contenía el agua para las 
abluciones de los sacerdotes, y 12 basas de bronce para el agua destinada a lavar el material del holocausto (1Re 7.23-37; 2Cr. 4.2-6). Otros templos sirios de Palmira estaban dotados de piscinas o conducciones de agua para las purificaciones, como el templo de Bel, consagrado el 6 de abril del 32 a la Triada Palmirena, Bel, Arhibôl y 'Aglibôl; delante del altar había una piscina en el patio. En el templo de Ba'alsamún, s. I, existía una conducción de agua para las abluciones.

Los autores cristianos dieron gran importancia a la oración y escribieron varios tratados sobre ella, como Orígenes, Tertuliano, Cipriano, Macario el Egipcio, Evagrio Póntico y Diodoco de Fótice. Todos estos tratados prueban la gran importancia que para el cristianismo primitivo tiene la oración. Una diferencia grande existe entre la oración de los monjes y la de los musulmanes. De la primera sólo se sabe que oraban. El Corán desarrolla la segunda.

\subsection{AYUNOS}

Eran continuos, aunque la comida era ligerísima: pan, agua, dátiles y algunas plantas del desierto. Teodoreto, en el Prólogo (5), afirma que los monjes sirios aplacaban las pasiones con los ayunos. Santiago (I.7) ayunaba continuamente. Marciano (III.3) comía sólo un poco de pan, en cantidad que no satisfaría la necesidad de un niño que acabara de dejar el pecho materno. Se cuenta que una libra de pan la dividía en cuatro partes para cuatro días, y cada día comía una porción. Había determinado comer todos los días al atardecer y no saciarse jamás, sino siempre tener hambre y sed, y conceder al cuerpo sólo lo suficiente para vivir. Afirmaba que si se tomaba alimento durante muchos días, se estaba demasiado débil en los días del ayuno para poder participar en la liturgia divina, y que en los días en que de nuevo tomaba alimento, comiendo más, se perjudicaba el estómago. Decía que era mejor comer todos los días sin saciarse, porque el verdadero ayuno es una continua hambre. Marciano proponía, continuamente, esta norma. Los hombres de su tiempo mantenían su cuerpo con poco alimento. Marciano (III.13) conocía el tiempo del ayuno.

Los que conocieron a Abramo (XVII.2) decían que domó su cuerpo con ayunos. Eusebio (XVIII.4), con 15 higos, pasaba las siete semanas del ayuno. Simeón (XXVI.5), mientras otros ascetas se alimentaban cada tres días, ayunaba durante toda la semana. Simeón (XXVI.7) se marchó a la aldea llamada Telanisso, situada en la falda de la montaña, donde se estableció. Encontró una pequeña celda y se recluyó en ella durante tres años, y quería ayunar 40 días, como Moisés y Elías. A Basso, que era superintendente de los sacerdotes de las afueras y que visitaba muchas aldeas, cuando el dijo que no creía que fuera virtud un suicidio, le contestó Simeón: "dame diez panes y un recipiente de agua, y si veo que mi cuerpo tiene necesidad de alimento, lo tomo". Se hizo como había dispuesto. Se colocaron los alimentos. Se cerró la puerta con fango. Al final de los días, llegó Basso y encontró el mismo número de panes. El recipiente del agua estaba intacto. Simeón ayunaba durante toda la Cuaresma (XXVI.9) durante 28 años.

Marana y Cira (XXIX.6) imitaron el ayuno de Moisés. Tres veces estuvieron sin comer el mismo tiempo que Moisés. Después de 40 días tomaron un poco de alimen- 
to. Imitaron otras tres veces el ayuno de Daniel durante tres semanas enteras, concediendo después un poco de alimento al cuerpo. Deseando visitar los santos lugares de la pasión de Cristo, llegaron a Jerusalem sin comer nada durante el viaje. Sólo después de llegar a la ciudad tomaron alimentos. También ayunaron durante la vuelta. Quisieron visitar la tumba de Tecla, la compañera de Pablo, que estaba en Isauria. Fueron y volvieron absteniéndose de alimentos. Los ascetas ayunaban continuamente, incluso cuando hacían viajes largos.

La Historia de los monjes sirios aporta datos concretos sobre la comida de los ascetas. Así, Juliano (II.2) tomaba como alimento, una sola vez a la semana, pan condimentado con unos granos de sal. Su bebida era el agua natural de una fuente, y de ésta tomaba, no hasta saciarse, sino según la necesidad del alimento tomado. Eusebio (IV.5) se alimentaba tres o cuatro días. Obligaba a su compañero a hacerlo todo el día. Más adelante de la biografía (IV.12) se afirma que tomaba un poco de alimento cada dos días. Publio (V.3), imponía a los que querían imitarlo, que cuando comiesen y bebiesen no lo hicieran hasta saciarse, sólo lo necesario para que viviese el cuerpo. Teotecno y Gregorio, sucesores en el episcopado a Publio, aceptaban el uso del aceite durante el tiempo de Pentecostés; después estaba prohibido tomarlo (V.5). Gregorio se abstenía totalmente del fruto de la vid, y no tomaba ni aceite, ni uvas pasas ni leche. Simeón el Viejo (VI.1) se alimentaba de plantas comestibles. Un asceta se alimentaba de dátiles que un hermano le llevaba.

Pedro el Gálata (IX.3) vivía en una tumba; bebía agua fresca y comía sólo pan, no todos los días, sino ayunando un día y comiendo el siguiente. Romano (XII.3) tomaba el alimento necesario para no morirse de hambre. Macedonio (XIII.3) no comía ni pan ni legumbres, sino granos de sorgo condimentados con agua.

En el Corán (II:179-183) se lee un texto amplio sobre el ayuno, que es el siguiente:

¡Oh, los que creéis! Se os prescribe el ayuno, de idéntica manera como se prescribió a quienes os precedieron - ¡tal vez seáis piadosos!- durante días contados. Aquel de vosotros que esté enfermo o de viaje, ayunará un número igual de otros días. Quienes pudiendo ayunar no lo hiciesen, darán en rescate la comida de un pobre. Quien voluntariamente dé más, eso será un bien para él. Que ayunéis os es un bien, si vosotros sabéis. En el mes de Ramadán se hizo descender el Corán como guía para los hombres y pruebas de la Guía y de la Distinción. Quien de vosotros vea el creciente del mes, pues ayune; quien esté enfermo o de viaje, ayunará un número igual de otros días. Dios quiere para vosotros lo fácil y no os quiere lo difícil. ¡Terminad el período de ayuno! ¡Ensalzad a Dios por lo que os ha dirigido! Tal vez seáis agradecidos. Cuando te pregunten mis siervos acerca de Mí, diles que estoy cerca, que contesto al ruego del que pide cuando Me invoca. ¡Que ellos me respondan y crean en Mí! Tal vez estén bien guiados. Os declaro lícito, la noche del ayuno, la visita a vuestras mujeres; ellas son vuestro vestido y vosotros sois su vestido. Dios supo que os traicionabais a vosotros mismos, pero volvió a vosotros y os perdonó. Ahora cohabitad con ellas y pedid lo que Dios os ha prescrito. Comed y bebed hasta que os aparezca distinto el hilo blanco del negro en la aurora. A continuación, ayunad completamente hasta la noche. No cohabitéis con ellas. Vosotros permaneced en oración en las mezquitas. Ésas son las prescripciones de Dios. No os acerquéis a ellas para transgredirlas. Así aclara Dios sus aleyas a los hombres. Tal vez seáis piadosos. 
El ayuno está mandado en las Sagradas Escrituras hebreas y cristianas. Era señal de penitencia y aflicción interior, al que se añadía la oración para aplacar a Dios y obtener su misericordia (Le. 19.29; Nu. 30.14-26; To. 12.8; 1Mac. 3.47; 2Mac. 13.12; Mt. 17.20; Hch. 13.2-3; 14.22; 2Cor. 6.5; 11.27). Se prescribe el espíritu con el que se debe ayunar (Is. 58.3-7; Je. 14.12; Mt. 6.16-18). Era señal de luto y tristeza por las calamidades (Jn. 20.26; Sam. 31.13; Je. 41.2; 52.12; Za. 7.2-5; 8.9; Mt. 9.15).

Clemente de Alejandría es el autor de un Discurso sobre el Ayuno, que se ha perdido. En la Tradición Apostólica de Hipólito se dan las normas para el ayuno. El ayuno debía hacerse todos los días. Debía hacerse los días cuarto y sexto de la semana, según Pedro de Alejandría.

En el ayuno, los musulmanes tienen un fuerte carácter, que los une con el monacato. El ayuno está recomendado en el Antiguo y en el Nuevo Testamento. Isaías (58.3-7) recuerda que el ayuno es el complemento de la piedad sincera. Después del destierro de Babilonia, se instruyeron nuevos ayunos (Za. 7.5, 8-14). Jesús se preparó para su ministerio ayunando cuarenta días y cuarenta noches en el desierto (Mt. 4.1-2; Lc. 4.1-2). Moisés se preparó para recibir las tablas de la Ley ayunando (De. 9.9.11) y Elías para encontrarse con Dios en el monte Horeb (1Re. 18.8). Los misioneros del Evangelio prepararon la predicación con ayunos (Hch. 13.2-3; 14.23). Pablo alude a sus ayunos (2Cor. $6-5 ; 11.27)$.

\subsection{LIMOSNA}

Los monjes sirios fueron grandes limosneros e hicieron continuas obras de caridad con los necesitados. Santiago (I.7), siendo obispo, se preocupaba de las viudas y de los huérfanos. En la vida de Eusebio (IV.4) se lee que la ley divina impone amar al prójimo como a uno mismo, y es propio de la excelencia de la caridad hacer participar a muchos de la común riqueza. Pablo había defendido que toda la ley y los profetas se resumían en amar al prójimo como a uno mismo. Los ascetas sirios cumplieron esta indicación del apóstol. Teodosio (X.3) se preocupaba, según sus posibilidades, de las necesidades de los pobres, de asistir a los huéspedes (X.4), y encomendaba este cuidado a hombres de ánimo equilibrado y que tenían amor al prójimo. Publio (V.2) tenía un único deseo: servir a los que le llamaban. Se preocupaba de los huéspedes (V.2). Masima se preocupaba del cuidado debido a los extranjeros y a los pobres, tan intensamente, que abría sus puertas a todos los que acudían a él. Se cuenta que tenía dos recipientes, uno de pan y otro de aceite, y socorría a todos los necesitados. Los recipientes los tenía siempre llenos.

En la bibliografía de Domnina (XXX.6), se narra que en Egipto algunos monasterios tenían más de 5.000 ascetas que trabajaban y cantaban himnos al Señor, y que procuraban, por medio del trabajo, el alimento necesario y ayudaban a los extranjeros que llegaban y a los pobres. A Simeón (XXVI.11) acudían algunos llevando paralíticos, otros buscando la salud para los enfermos. Los ascetas socorrían, no sólo a los pobres, sino a los enfermos de todo tipo de enfermedad.

Los musulmanes eran, igualmente, grandes limosneros. El Corán, II:211, se pregunta cómo debe hacerse la limosna: "Responde: «el bien que gastéis sea para los 
padres, los parientes, los huérfanos, los pobres y el viajero. El bien que hagáis, Dios lo conoce»". La limosna debe hacerse a todo el mundo, como en el monacato. El Corán II:255 exhorta a la limosna: “¡Oh los que creéis! De lo que hemos concedido, gastad en la limosna, antes de que venga un día en el que no habrá ni venta, ni amistad, ni intercesión, y en el que los infieles serán los injustos". Los bienes los ha dado Dios. De ellos hay que hacer la limosna durante la vida. Más adelante (II:263-275) se lee un largo párrafo sobre la limosna, lo que indica la extraordinaria importancia que Muhammad concede a la limosna. Dice así:

Quienes dan sus riquezas en la senda de Dios se parecen a un grano que da siete espigas y en cada espiga hay cien granos. Dios dobla la recompensa a quien quiere. Dios es inmenso, omnisciente. Quienes dan sus riquezas en la senda de Dios y a continuación no hacen seguir lo que gastaron ni de reproche ni de perjuicio, tendrán su recompensa junto a su Señor. No tengan temor, pues no serán los afligidos. Una hermosa palabra y perdón son mejores que una limosna seguida de perjuicio. Dios es rico, benigno. ¡Oh, los que creéis! No anuléis vuestras limosnas con el reproche y el perjuicio, como aquel que da lo que tiene delante de los hombres, pero no cree en Dios ni en el último Día. Se parece a las rocas cubiertas de tierra: cuando les cae encima un aguacero, las deja desnudas: los hombres no pueden en absoluto sacar provecho en la otra vida de lo que adquirieron. Dios no guía a la gente infiel. Quienes dan sus riquezas deseando satisfacer a Dios y conseguir la seguridad de sus almas, se parecen a un jardín situado en una altura, al que si cae encima un aguacero, sus frutos se duplican. Si no le cae el aguacero, el rocío le riega. Dios ve lo que hacéis. ¿Querría uno de vosotros tener un jardín repleto de palmeras y viñas, por el que corriesen riachuelos y hubiese toda clase de frutos, cuando la vejez hiciese mella en él y tuviese una descendencia enclenque? ¿Querría que se quemase el jardín en medio de una tromba acompañada de fuego? Así os aclara Dios sus aleyas: Tal vez meditéis. ¡Oh, los que creéis! Gastad en la limosna parte de los bienes que poseéis y de los que hemos hecho salir para vosotros de la tierra. No déis lo vil como limosna, pues no cogeríais lo vil a menos que cerraseis los ojos. Sabed que Dios es rico, alabado. Satanás os promete la pobreza y os manda la torpeza; Dios os promete perdón y favor. Dios es inmenso, omnisciente, da la sabiduría a quien quiere. A quien se da la sabiduría se le da un gran bien, pero no se acuerdan sino los poseedores de juicio. El gasto que hagáis o el voto que prometáis, Dios los conoce. Los injustos no tienen defensores. Si dais las limosnas en público, ellas os son buenas; si las ocultáis y las dais a los pobres, os son mejores y os servirán como expiación de vuestras maldades. Dios está bien informado de lo que hacéis. No te corresponde ¡Oh Profeta!, guiar a los infieles; Dios guía a quien quiere. Lo que gastáis en hacer bien es para vosotros mismos, pues no gastáis si no es por el deseo de contemplar la faz de Dios en la otra vida. Lo que gastéis en hacer bien, os será reintegrado y no seréis tratados con injusticia. Los pobres vergonzantes que se han visto constreñidos a la indigencia en la senda del Señor, que no pueden moverse por la tierra, aquellos a quienes el ignorante juzga ricos por la abstinencia en el pedir, que los conoce por su aspecto, que no piden inoportunamente, a esos pobres va a parar lo que gastáis en hacer el bien, pues Dios es omnisciente. Quienes gastan sus riquezas noche y día, secreta o públicamente, haciendo limosna, tendrán su recompensa junto a su Señor; no tengan temor, pues ellos no serán afligidos. 
Frecuentemente insiste en el consejo de dar limosna, como en III:86: "No alcanzaréis la piedad antes de que gastéis en la limosna parte de lo que amáis, y cualquier cosa que deis, Dios lo conoce". No se puede, pues, alcanzar la piedad sin hacer limosnas.

En IX:68 se ataca a los hipócritas que cierran sus manos para no dar limosnas. En IX:60, señala nuevamente a quiénes deben darse limosnas: "las limosnas son para los necesitados, los pobres, quienes por ellos actúan, quienes tienen sus corazones dispuestos a aceptar el Islam; deben darse para el rescate de los esclavos e insolventes, para la senda de Dios y el viajero (...). Dios es omnisciente, sabio".

En el monacato no se mencionan limosnas para rescatar esclavos y para pagar deudas.

En IX:99-100 se refiere Muhammad concretamente a la limosna entre los beduinos:

Entre los beduinos hay quienes consideran como un vejamen lo que gastan en la limosna, y en la senda de Dios, y esperan que os llegue, en el transcurso de las vicisitudes de la suerte, un mal momento, pero Dios es oyente, omnisciente. Entre los beduinos hay quienes creen en Dios y en el último Día y consideran lo que gastan en la limosna y en la senda de Dios como ofrendas hechas a Dios y como plegarias del Enviado. ¿Acaso no les sirven de ofrenda? Dios les hará entrar en su misericordia.

La limosna debe hacerse por Dios (XXX:38). La limosna que se da "buscando la faz de Dios, crece junto a Él. Quienes dan limosna, ésos recibirán doble recompensa". El Corán, LVII:7, insiste en la recompensa de la limosna: "Quienes de entre vosotros creen y gastan en la limosna, tendrán un gran salario".

Incita Muhammad (LVII:10) a dar limosna: “¿Qué os ocurre que no gastáis en la senda de Dios?". Se recomienda la limosna entes de entrevistarse con Muhammad (LVIII:13-14):

¡Oh, los que creéis! Cuando veáis en privado al Enviado, enviad por delante de la conferencia una limosna: esto es mejor y más puro para vosotros. Si no encontráis medio para hacerla, ciertamente Dios es indulgente, remisorio. ¿Temeréis el hacer preceder las limosnas a la conferencia? Cuando no lo hagáis y Dios vuelva de su rigor para con vosotros, ¡Cumplid la oración! ¡Dad la limosna! ¡Obedeced a Dios y a su Enviado! Dios está bien informado de lo que hacéis.

Y antes de que llegue la muerte (LXIII:10): "gastad de lo que se os ha concedido en dar limosnas antes de que la muerte se presente a cada uno de vosotros, antes de que tenga que decir: «Señor mío ¿Por qué no me retrasas la muerte por un plazo pequeño? Daré limosna y estaré entre los justos»".

Todavía se lee en el Corán, LXIV:16, una última recomendación de dar limosnas: "Gastad en la limosna. Es mejor para vosotros mismos".

Algunas ideas se leen en los Evangelios, como que Dios duplicará la limosna. 
En las Sagradas Escrituras, la limosna es sumamente recomendada (Ex. 23.11; Le. 19.10; 23.22; De. 24.19-22; 1Re. 17.10-16; Sal. 40.1; 81.4; Pr. 3.27; 11.25-26; 14.21; 21.13). Para el discípulo de Jesús, Santiago (1.27), la religión pura y auténtica a los ojos de Dios Padre consiste en mirar por los huérfanos y las viudas en sus tribulaciones.

\subsection{PROHIBICIÓN DE ALIMENTOS}

No se menciona nunca el vino en la dieta alimenticia de los ascetas sirios. De Gregorio se afirma expresamente que no lo tomaba. Tampoco se comía nunca carne, y menos de cerdo.

En las Sagradas Escrituras se prohíben determinados alimentos, como el cerdo, al que se considera inmundo (Lc. 11.7; De. 14.8; Is. 65.4; 66.3; 1Mac. 1.50).

El vino estaba prohibido en II:219 y V:90-91 en el Corán. En cambio, XLVII:15, indica que en el Paraíso habrá ríos de vino que serán delicia de los bebedores. En V:90-91 se lee: "el vino, el juego de maysir, los ídolos y la flechas son abominaciones procedentes de la actividad de Satanás (...). Satanás querría suscitar entre vosotros la enemistad y el odio mediante el vino y el juego del maysir y apartaros del recuerdo de Dios, de la Plegaria”. El Corán, II:173; V:3; VI:145; XVI:115, prohíbe comer carne mortecina, la sangre, el cerdo y todo animal sobre el que se haya invocado un nombre diferente del de Dios.

Muhammad se parece a los monjes en la abstención del vino y de la carne de cerdo.

\subsection{PEREGRINACIONES}

Los monjes sirios peregrinaban con frecuencia a Jerusalem, ciudad santa para cristianos y paganos, como Marana y Cira (XXIX.7), Pedro el Gálata (IX.2) y Teodoreto de Cirro (Cira 11.71).

El Corán menciona frecuentemente la peregrinación a la Ka'ba (II:158.196200.203; III:97; IX:3; XXII:26-29). La peregrinación hacia Safa y Marwa, dos elevaciones pequeñas en La Meca, en recuerdo de la carrera que hizo Agar en busca de agua para su hijo Ismael (Ge. 21.15.19).

Pronto, los cristianos peregrinaron a Jerusalem. Elena, la madre del emperador Constantino I, visitó Jerusalem, y Egeria, monja de origen hispano, a comienzos del s. V recorrió los lugares sagrados del Oriente: Jerusalem y sus alrededores, Belem y Betania, el Sinaí, Egipto, Siria y Mesopotamia.

Juan Bautista predicaba un bautismo con agua de penitencia, al que se sometió Jesús (Mt. 3.13; Mc. 1.9-11; Lc. 15-20; Jn. 1.15-42).

El rito de iniciación en el cristianismo era el bautismo de agua, que perdonaba todos los pecados cometidos. Fue instituido por Jesús (Mt. 28.19). 


\subsection{REVELACIONES E INSPIRACIONES}

Los ascetas sirios mantenían conversaciones con Dios. Juliano (II.4) se introdujo en el desierto 50 estadios. Se apartaba de todo trato humano, replegándose sobre sí mismo, se dirigía sólo a Dios y contemplábalo como en un espejo, la divina e inefable belleza. Después de 10 días volvió, como Moisés, de la montaña y de la inefable visión. Es una visión de Dios como la de Moisés en el Sinaí.

Marciano (III.2) estaba en conversación con el Señor del Universo, oía su dulce voz. Eusebio (IV.5) exhortaba al diálogo continuo con Dios, y no privarse un momento de esta actividad. Simeón el Viejo (VI.1) dialogaba continuamente con el Dios del Universo.

Dios le recomienda a Muhammad la revelación a trozos (LXXV:16) por medio del Espíritu (XXVI:193-196; XVI:104) o a través de los ángeles (XVI:2; XV:8; LIII:510; LXXXI:19-21). En II:91 se afirma claramente que Gabriel es el encargado de la transmisión. Este relato no va acompañado de visiones casi nunca (VIII:45; XLVIII:27). Cuando sucede (XVII:1) se trata de un milagro. Entonces, lo importante es lo visto (LIII:10-11; LXXXI:19).

A los monjes, la inspiración les venía frecuentemente directa de Dios. Unas veces era a través de los ángeles, y otras veces se aparecen monjes santos.

En las Sagradas Escrituras, Dios se aparece (Ge. 32.24-30; Ex. 3.2; Jos. 5.13).

\subsection{CRISTOLOGÍA}

La cristología de los monjes sirios es ortodoxa y están bien informados de la persona de Jesús. En la vida de Juliano (II.16) se le llama Maestro, al igual que Teodoreto de Cirro en su tratado Sobre el amor de Dios (XXXI. 10.11). La Historia de los monjes sirios menciona la pasión en las vidas de Santiago (I.6) y de Marciano (III.10). El nombre más frecuente que recibe es el de Señor, ya en el Prólogo (11), o en las vidas de Santiago (I.6.11), de Juliano (II.16), de Marciano (III.8), de Eusebio (IV.4), de Público (V.5.10), de Afraate (VIII.1.8), de Macedonio (XIII.5.11), de Acepsima (XV.6), de Abramo (XVII.3.6), de Santiago (XXI.28), de Simeón (XXVI.17.18.28), de Marana y Cira (XXIX.7), de Domnina (XXX.5). El término Unigénito aplicado a Cristo se encuentra en las vidas de Santiago (I.10) y de Afraate (VIII.12). En las vidas de los monjes sirios no se menciona a la Madre de Jesús.

En el Corán ha quedado bien clara la idea que Muhammad tiene de Jesús. A los judíos, les dice Dios (II:81):

Hemos dado el libro a Moisés, y después de él, le hemos hecho suceder por enviados. Hemos dado pruebas a Jesús, hijo de María, y le hemos auxiliado con el Espíritu Santo. Pero cada vez que os ha venido un Enviado, con lo que no deseaban vuestras almas, os habéis enorgullecido y a una parte la habéis acusado de impostora, y a otra, la habéis matado.

En este párrafo se afirma tajantemente que Dios dio la Ley a Moisés, que envió a Jesús, auxiliado por el Espíritu Santo, que le habían acusado de impostor y que le 
mataron. En este texto queda un eco de los Evangelios. Jesús fue tenido por impostor y crucificado; auxiliado por el Espíritu Santo. Lo mismo se afirma en II:254: "Hemos hecho sobresalir a unos profetas respecto de otros. Entre ellos hay unos a quienes Dios habló; a otros los elevó en jerarquía: dimos a Jesús, hijo de María, las pruebas y le auxiliamos con el Espíritu Santo”. Dios envió una jerarquía de profetas, y Jesús es el primero.

En III:43-51 describe la biografía de Jesús en los siguientes términos:

Y he sido enviado a los Hijos de Israel diciendo: «He venido a vosotros con una aleya procedente de vuestro Señor: Yo os haré, de arcilla, algo semejante en la forma a los pájaros; soplaré en ella y se transformará en pájaros con el permiso de Dios; curaré al ciego de nacimiento y al leproso; resucitaré a los muertos con el permiso de Dios. Os anunciaré lo que coméis y lo que atesoráis en vuestras casas. Realmente, en esto hay una aleya para vosotros, si sois creyentes. Os he sido enviado para corroborar lo que me ha precedido: el Pentateuco, y para permitiros parte de lo que se os prohibió; he venido a vosotros con una aleya procedente de vuestro Señor. Temed a Dios y obedecedme. Dios es mi Señor y vuestro Señor, ¡Adoradle! Ése es un camino recto». Cuando Jesús se dio cuenta de su incredulidad dijo: «¿Quiénes son mis defensores en la senda de Dios?». Respondieron los Apóstoles: «Nosotros somos los defensores de Dios. Creemos en Dios. Atestigua que nosotros le estamos sometidos. ¡Señor nuestro! Creemos en lo que revelaste y seguimos al Enviado: inscríbenos con los testigos». Los judíos tramaron una intriga contra Jesús, pero Dios tramó contra ellos. ¡Dios es el mejor de los intrigantes! Acuérdate de cuando Dios dijo: «¡Oh, Jesús! Yo te llamo y te elevo hacia Mí, te alejo de quienes no creen y coloco a quienes te han seguido por encima de quienes no creen hasta el Día de la Resurrección. En seguida tendrá lugar vuestra vuelta hacia Mí, y juzgaré, entre vosotros, aquello en que discrepáis. A quienes no creen, los atormentaré con un duro castigo en esta vida y en la otra. No tendrán auxiliares. A quienes crean y hagan obras pías, les daré su retribución: Dios no ama a los injustos». Esto te lo recitamos ¡oh, Profeta!, tomándolo de las aleyas y de la palabra divina.

Jesús es, ante Dios, igual que Adán. Luego le dijo: Sé, y fue. Jesús es, pues, el más grande de los profetas, anterior a Muhammad.

Al referirse Muhammad contra los judíos de Medina (IV:156) afirma:

Ellos dicen: «Nosotros, ciertamente, hemos matado al Mesías, Jesús, hijo de María, enviado de Dios», pero no le mataron ni le crucificaron, pero a ellos se lo pareció. Quienes discuten y están en duda acerca de Jesús, no tienen conocimiento directo de él: siguen una opinión, pues con exactitud no le mataron. Al contrario, Dios le elevó hacia Él, pues Dios es poderoso y sabio.

Este párrafo es importante. Se afirma tajantemente que Jesús es el Mesías, enviado de Dios, y la muerte aparente de Jesús. Dios le elevó a Sí. Todas son creencias fundamentales de Muhammad sobre Jesús. La muerte de Jesús es aparente.

Dios dio a los judíos el Pentateuco, a los profetas y a Jesús (V:50).

Jesús es un simple profeta (V:109-119). La descripción es la siguiente: 
Acuérdate de cuando Dios dijo: «¡Jesús, hijo de María, recuerda el beneficio que dispensé sobre ti y sobre tu madre cuando te auxilié con el Espíritu Santo diciendo: «Hablarás a los hombres en la cuna con madurez». Acuérdate de cuando te enseñé el Libro, la Sabiduría, el Pentateuco y el Evangelio, y cuando creaste de arcilla algo semejante a la forma de los pájaros, con mi permiso, y soplaste en ellos y fueron pájaros con mi permiso; cuando curaste al ciego de nacimiento y al leproso con mi permiso; cuando hiciste salir a los muertos de su sepulcro con mi permiso, y cuando aparté de ti a los Hijos de Israel en el momento en que les traías pruebas manifiestas; quienes entre ellos no creían, dijeron: «Esto no es más que magia manifiesta». Acordaos de cuando inspiré a los apóstoles diciendo: «Creed en Mí y en mi Enviado». Respondieron: «Creemos: atestigua que nosotros estamos sometidos a la voluntad de Dios». Acordaos de cuando dijeron los Apóstoles: «jJesús, hijo de María! ¿Puede hacer descender tu Señor una mesa servida desde el cielo?». Respondió: «Temed a Dios si sois creyentes». Dijeron: «Desearíamos comer de ella; nuestros corazones se tranquilizarían, sabríamos que nos has dicho la verdad y estaríamos entre los testimonios». Jesús, hijo de María, dijo: «¡Dios mío! ¡Señor! ¡Haznos descender una mesa servida desde el cielo que para el primero y el último sea una fiesta y un prodigio procedente de Ti! ¡Provéenos, pues Tú eres el mejor de los proveedores!». Dios dijo: «Os la hago descender, pero a quien de entre vosotros no crea después, le castigaré con un tormento tal, que no volveré a castigar con él a nadie de los mundos». Acordaos de cuando Dios dijo: «Jesús, hijo de María ¿has dicho acaso a los hombres "Tomadme, junto a mi madre, como dos dioses, prescindiendo de Dios"?». Respondió: «¡Loor a Ti! No me incumbe decir lo que no es verdad; si lo hubiese dicho, lo sabrías; Tú sabes lo que hay en mi alma, pero yo no sé lo que hay en tu alma. Tú, Tú conoces perfectamente lo oculto. No les he dicho sino lo que me mandaste: “Adorad a Dios, mi Señor y vuestro Señor”. He sido testimonio el tiempo que he permanecido entre ellos. Cuando me llamaste, Tú fuiste su observador; Tú eres testigo sobre todas las cosas. Si los atormentas, tienes derecho, pues son tus servidores; si los perdonas, tienes derecho a hacerlo; Tú, Tú eres el Poderoso, el Sabio». Dios dice: «Éste es el día en que sacarán provecho de su veracidad los justos: Tendrán unos jardines en que, por debajo, correrán los ríos. Eternamente permanecerán en ellos». ¡Esté Dios satisfecho de ellos, pues ellos estuvieron satisfechos de Él! ¡Ése es el éxito mayor!

La tradición rabínica desacredita a Jesús como hechicero. Justino, a mediados del s. II, se vio obligado a refutar esta calumnia (Dial. 69.7; 108.2; I Ap. 30). La acusación pasó de los judíos a los paganos, que acusaron al cristianismo de magia (Lact. Div. Inst. V.3.19; Iust. Apol. 30; Orig. Contra Cels. 7.69).

En VI:84 se da la lista de todos los profetas, hasta Muhammad:

Y a Abraham le dimos por sucesores a Isaac y a Jacob; guiamos a cada uno de ellos; anteriormente guiamos a Noé, y entre su descendencia guiamos a David, a Salomón, a Job, a José, a Moisés, a Aarón, pues así recompensamos a los benefactores. Y guiamos a Zacarías, a Juan, a Jesús, a Elías; todos están entre los justos. Y guiamos a Ismael, a Elías, a Jonás y a Lot; a cada uno de ellos le distinguimos sobre los mundos, así como a parte de sus padres, de sus descendientes, de sus hermanos, y los escogimos y los condujimos al camino recto. Ésta es la dirección de Dios; guía con ella, entre sus siervos, a quien quiere. Si los profetas hubiesen asociado, les hubiese sido vano todo lo que hicieron. Ésos son aquellos a quienes dimos el Libro, la Sabiduría y la Profecía. 
Muhammad ha incluido en la lista de profetas a muchos que no figuran en las Sagradas Escrituras. El profetismo está bien documentado en Israel. El profeta hablaba en nombre de Dios (Ex. 4.15; 7.1). Dios promete profetas a Israel (De. 18.14-22). El oficio de los profetas consiste en dar testimonio, enseñar, consolar (Is. 6.8-13; Je. 1.4-19; Ez. 2.1-3.27). Algunas veces predicaban con su conducta (Je. 16.1-21; Ez. 4.1-5.17; Zac. 13.4). Había falsos profetas y profetas de los ídolos (1Re 18.19; 22.1112; Je. 14.14; 23.9; 29.8; Ez. 13.2; Mi. 3.5). A Jesús se le tenía por más que un profeta (Mt. 11.9; Lc. 7.16; 24.25).

En XIX:31-41, presenta nuevamente a Jesús, profeta de Dios:

Pero éste respondió: «Yo soy siervo de Dios. Él me ha dado el Libro y me ha hecho Profeta; me bendice dondequiera que esté y me ha prescrito, durante todo el tiempo que viva, la plegaria, la limosna y el cariño filial a mi madre. Dios no me ha hecho violento, orgulloso. ¡Tenga la paz del día en que nací, del día en que muera y del día en que sea devuelto a la vida!» Ése es Jesús, hijo de María, Verbo de la Verdad sobre el cual discuten los cristianos. Dios no tiene por qué adoptar un hijo ¡Loado sea! Cuando decreta una cosa, no tiene más que decir «iSea!», y es. Dios es mi Señor y vuestro Señor. ¡Adoradle! Ése es el recto camino. Las sectas discrepan entre sí. ¡Ay de quienes no hayan creído en la vista de un gran día! ¡El día en que vengan a Nos, escuchen y observen! Pero los injustos, hoy, están en un extravío evidente. Adviérteles, Mahoma, acerca del día de la Pérdida, cuando se decrete la Orden, mientras ellos estén en descuido, mientras ellos no crean. Cierto, Nos heredaremos la tierra. Quienes sobre ella están hacia Nos, serán devueltos.

En este párrafo se afirma tajantemente que Jesús no es Hijo de Dios. Dios no tiene hijos. A Moisés y a Jesús, Dios los coloca en una calma tranquila e irrigada, es decir, que en la jerarquía de los profetas son los dos mayores.

En LVII:27 se lee que Dios dio el Evangelio a Jesús. En IV:169-171 se lee:

¡Gente del Libro! No exageréis en vuestra religión ni digáis, sobre Dios, más que la verdad. Realmente, el Mesías, Jesús, hijo de María, es el Enviado de Dios, su Verbo, que echó a María un espíritu procedente de Él. Creed en Dios y en sus enviados, pero no digáis «Tres». Dejadlo, es mejor para vosotros. Realmente, el Dios es un dios único. ¡Loado sea! ¿Tendría un hijo cuando tiene lo que está en los cielos y en la tierra? ¡Dios basta como garante! Ni el Mesías ni los ángeles próximos al Señor han tenido a menos el ser servidores de Dios. A quienes se enorgullecen y desdeñan ser sus servidores, los reunirá a todos hacia Él.

Jesús es sólo el Mesías, el enviado de Dios, su Verbo. No hay Trinidad, pues Dios es uno. Dios no tiene hijos. El Mesías y los ángeles son siervos de Dios. Muhammad (IV:155) defiende a María de una enorme calumnia. Posiblemente alude el Profeta a la leyenda judía (Talmud) de que Jesús nació de la unión con un soldado romano llamado Pandera, a la que alude el evangelista Juan (8.41) ya en la década del 90.

Algunos términos con que el Corán califica a Jesús se encuentran -como Mesíasen el Nuevo Testamento, aplicados a él (Jn. 1.41); verbo (Jn. 1.1); enviado (Lc. 9.48; 
Jn. $5.30 ; 6.57 ; 17.18 ; 20.21)$. En el Nuevo Testamento la concepción cristiana sobre Jesús es totalmente diferente. Se le considera Hijo de Dios (Mt. 3.17; 4.3; 14.33; 16.16; 21.37; 26.63; 27.43.54; Mc. 1.1; Hch. 8.37; 9.20), igual al Padre (Jn. 1.1; 5.18; $10.30 ; 14.9 ; 16.15 ; 17.10 ; 20.28)$.

En la última cita del Corán V:77-79, sobre la Trinidad, remacha lo expuesto con anterioridad: "Son infieles quienes dicen: Dios es el tercero de una triada. No hay dios, sino un Dios único (...) El Mesías, hijo de María, no es más que un Enviado. Antes que él han existido enviados. Su madre era verídica. Ambos comían alimentos".

La Trinidad es una concepción platónica sobre la esencia de Dios (Agust. De Civ. Dei 10-29). No tiene prueba en el Nuevo Testamento. El primero que la mencionó fue Atenágoras de Atenas, que fue un apologista neoplatónico, en su Súplica a favor de los cristianos, hacia el 177, dirigida a los emperadores Marco Aurelio y Lucio Vero:

Así pues, suficientemente queda demostrado que no somos ateos, pues admitimos a un solo Dios... ¿Quién pues, no se sorprenderá de oír llamar ateos a quienes admiten a un Dios Padre y a un Dios Hijo y un Espíritu Santo, que muestran su potencia en la unidad y su distinción en el orden?

La Trinidad es una fosa insalvable entre Muhammad y los monjes ortodoxos.

En las primeras frases del Evangelio de Juan, en la década de los 90', se afirma tajantemente qué es Dios: al principio era el Verbo, y el Verbo estaba en Dios, y el Verbo era Dios.

Harnack, el gran estudioso protestante liberal del dogma primitivo, defendió que la gran aportación de Jesús a la Historia de las Religiones era la paternidad de Dios, bien clara en el Padre Nuestro y en el Hijo pródigo (Lc. 15.11-32). Esta creencia la tuvieron, con la más absoluta seguridad, los monjes sirios, pero está ausente en la mentalidad de Muhammad.

\section{17. SACRAMENTOS}

El Corán desconoce los sacramentos cristianos, tan sólo hay una probable mención a la Eucaristía (V:112-115), que es el centro de la liturgia de los monjes cristianos:

Acordaos de cuando dijeron los Apóstoles: «jJesús, hijo de María! ¿Puede hacer descender tu Señor una mesa servida desde el cielo?». Respondió: «Temed a Dios si sois creyentes». Dijeron: «Desearíamos comer de ella; nuestros corazones se tranquilizarían, sabríamos que nos has dicho la verdad y estaríamos entre los testimonios». Jesús, hijo de María, dijo: «¡Dios mío! ¡Señor! ¡Haznos descender una mesa servida desde el cielo que para el primero y el último sea una fiesta y un prodigio procedente de Ti! ¡Provéenos, pues Tú eres el mejor de los proveedores!». Dios dijo: «Os la hago descender, pero a quien de entre vosotros no crea después, le castigaré con un tormento tal, que no volveré a castigar con él a nadie de los mundos»

Los grandes estudiosos del dogma cristiano del s. XX, Adolf von Harnack, HansJoachim Schoeps, Adolf Schlatter, Julius Wellhausen, defendieron la tesis de que 
Muhammad era un ebionita. El Islam había recibido, no sólo ideas judías y cristianas, sino también judeo-cristianas. Harnack relaciona el Islam con el judeo-cristianismo de influjo gnóstico, como los elkasaítas, que según las últimas investigaciones, son los sabeos mencionados en el Corán (II:59; V:73; XXII:17), que dice: "Quienes creen, quienes practican el judaísmo, los cristianos y los sabeos -quienes creen en Dios y en el último Día y hacen obras pías-, tendrán su recompensa junto a su Señor. No hay temor por ellos, pues no serán entristecidos" y "Dios os distinguirá, en el día de la Resurrección, entre quienes hayan creído, hayan practicado el judaísmo, los sabeos, los cristianos y los magos".

Hoy se admite la existencia de escritos judeo-cristianos en lengua árabe. Ya en 1926 el famoso profesor de Tübingen, Shlatter, escribió:

La chiesa giudaica, tuttavia, si era estinta solo in Palestina, a ovest del Giordano. Comunità cristiane con usanze giudaiche continuavano a esistere, invece, nelle regioni orientali, nella Decapoli, nella batanea, presso i nabatei, ai margini del deserto siriaco e in Arabia, completamente staccate dal resto della cristianità e senza comunione con essa. [...] L'ebreo era per il cristiano soltanto un nemico e l'opinione greca, che guardava ai massacri compiuti dai generali di Traiano e di Adriano come al destino ben meritato dei cativi e disprezzati ebrei, era penetrata anche nella chiesa. Anche i suoi capi, che vivevano e insegnavano a Cesarea, come Origene ed Eusebio, rimasero stranamente ignari della fine di Gerusalemme e dalla sua chiesa.

Schlatter aggiunge tuttavia: nessuno dei capi della chiesa imperiale immaginava che per questa cristianità da essi disprezzata sarebbe venuto il giorno in cui essa avrebbe scosso il mondo e distrutto gran parte del mondo ecclesiastico da essi costruito; quel giorno venne quando Muhammad riprese il patrimonio preservato dai giudeo-cristiano, la loro coscienza di Dio, la loro escatologia che annunciava il Giorno del giudizio, i loro costumi e le loro leggende e, in qualità di "inviato di Dio", intituì un nuovo apostolato.

Esta tesis la acepta plenamente el mayor teólogo católico del momento, H. Küng, ${ }^{20}$ partidario de un diálogo permanente con el Islam, y nosotros.

Juan Damasceno considera a Muhammad un cristiano herético, por ser un judeocristiano ebionita. Los ebionitas vivían en Palestina y en Siria, y los elkasaítas en Mesopotamia. De los ebionitas han tratado Ireneo, Tertuliano, Hippólito, Orígenes, Teodoreto y Timoteo, lo que prueba que les daban importancia. De los segundos, Hippólito, Orígenes y Epifanio. A ambos se les considera de la primera comunidad de Jerusalem. Se los tenía por heterodoxos.

Para los ebionitas y elkasaítas, el cristianismo era un judaísmo purificado. Dios se manifiesta al hombre a través del profeta verdadero, bajo personajes distintos. Primero fue Adán, luego Moisés, y después Jesús. El título "Hijo de Dios" sólo es aplicable a Jesús, pero sólo es un profeta y un maestro, no un redentor. Cuando las verdades predicadas por Moisés se corrompieron, fue necesaria otra nueva manifestación en la persona de Jesús. La doctrina de Muhammad es un monoteísmo radical, que excluye toda distinción entre personas divinas. Todo esto está muy próximo a la mentalidad de Muhammad.

20 KÜNG 2004, 56-64. 
Los judeo-cristianos ${ }^{21}$ formaban una comunidad importante en Antioquía, como se deduce de las Homilías contra los judios de Juan Crisóstomo, pronunciadas en Antioquía entre los años 386 y 387 . En cambio, en Belem, estaban en decadencia en tiempos de Jerónimo. No se puede dudar que Muhammad es un judeo-cristiano, pero esto no impide que sea un grandísimo religioso y el profeta de los árabes.

\subsection{LUCHA CONTRA PAGANOS Y JUDÍOS}

Los monjes sirios lucharon contra el paganismo.

En tiempos de Santiago (I.4) florecía la loca idolatría de los hombres y las adoraciones a las estatuas sin alma. Se apropiaban del culto divino, mientras se abandonaba el culto al verdadero Dios. Se despreciaba a los que no participaban en esta borrachera, contra la que luchó el asceta. La región donde se asentó Simeón el Viejo era politeísta. El asceta plantó la verdadera religión. Pedro el Gálata purificó a un coribante (IX.4), lo que indica que Cibeles recibía culto.

Muhammad luchó contra el paganismo. Baste recordar la purificación de la Ka'ba de los ídolos, y las guerras que sostuvo contra los paganos. En La Meca, los paganos boicotearon a los musulmanes prohibiendo casarse con ellos y comerciar.

Muhammad era un pacifista y con las guerras contra los paganos y judíos se vio obligado a combatir. En 624, para proteger una caravana que volvía de Siria, los mercaderes enviaron en su socorro unos mil guerreros, que fueron derrotados por los musulmanes, que vencieron en Badr (VIII:7-8), entre Medina y La Meca. En el año siguiente, 615, hubo un segundo choque armado en los arrabales de Medina, en Uhud. Los musulmanes estuvieron por segunda vez a punto de ser derrotados (III:139-143). En 627 tuvo lugar el último encontronazo contra los paganos. Es la llamada campaña del foso en Medina (XXXIII:9-27).

Después de esta campaña, los musulmanes lucharon contra las tribus judías de Medina. Entre 600 y 900 judíos fueron degollados y las mujeres y los niños, esclavizados (XXXII:26-27). En 628 se firmó un tratado entre musulmanes y paganos. La actitud contra los cristianos se endureció (IX:29-39). Sin embargo, Muhammad se presentó como enviado a judíos y cristianos (V:19).

Los monjes sirios consideraban a los judíos como incrédulos en la vida de Simeón el Viejo (VI:2), pero no se registra en sus vidas una oposición ferozmente antijudía, con destrucción de sinagogas.

\subsection{CRISTIANOS}

El Corán cita frecuentemente a los cristianos, y es favorable a ellos. Ya se han recordado algunas menciones al referirse a los sabeos. En II:105 se lee: "Dicen: «No entrará en el Paraíso sino quien sea judío o cristiano». Esos son sus deseos". Y en II:129: "Dicen: «Sed judíos o cristianos, estaréis en un buen camino»".

21 Mimouni 1998; ID., coord., 2001, passim.; Mohammed Abd-El-Jalil 2006. Se estudian los ebionitas y elkasaítas. Sobre los ebionitas habla Ireneo de Lyon (BELlini - MAschio 1979, 1.26.2; V.1.3). 
Sin embargo, en V:17-22, cambia el Corán de idea y arremete contra cristianos y judíos:

Hemos aceptado la alianza de un grupo de quienes dicen: «Nosotros somos cristianos», pero ellos han olvidado una parte de las cosas que se mencionaban en ella. Hemos suscitado entre ellos la enemistad y el odio hasta el día de la Resurrección. Dios les anunciará lo que hacían. ¡Gente del Libro! Nuestro Enviado ha venido exponiéndoos gran parte del Libro que ocultabais, pero os ha perdonado mucho de lo ocultado. Procedente de Dios os han venido una luz y un Libro explícito: Dios guía con ello a quienes buscan su satisfacción en las sendas de la paz; los sacará de las tinieblas hacia la luz, con su permiso, y los conducirá hacia el recto camino. Realmente, no creen quienes dicen: «Dios es el Mesías, hijo de María». Responde: «¿Quién podría oponerse a dios si desease hacer morir al Mesías, hijo de María, a su madre y a quienes están en toda la tierra?». Dios tiene el señorío de los cielos, de la tierra y de lo que está entre ambos. Crea lo que quiere. Dios es poderoso sobre todas las cosas. Judíos y cristianos dicen: «Nosotros somos los hijos, los amigos amados de Dios». Responde: «¿Por qué os castiga por vuestros pecados? No, vosotros sois seres humanos de los que Él creó»». Perdona a quien quiere y castiga a quien quiere. Dios tiene el señorío de los cielos, de la tierra y de lo que está entre ambos. A Él conduce el Porvenir. ¡Gente del Libro! Os ha venido nuestro Enviado que os explica la interrupción de la serie de los enviados, para que nos digáis: «No nos ha venido ningún albriciador ni amonestador». Os ha llegado un albriciador, un amonestador. Dios es poderoso sobre todas las cosas.

Los cristianos han rechazado el Enviado y la revelación. Afirma que no creen los que tienen al Mesías, o sea, a Jesús, por Dios.

El mismo ataque contra los cristianos se encuentra en V:76-81:

Son infieles quienes dicen: «Dios es el Mesías, hijo de María», pues el Mesías dijo: «Hijos de Israel: Adorad a Dios, mi Señor y vuestro Señor». Ciertamente, a quien asocia a Dios, Dios le prohibirá entrar en el Paraíso: su asilo será el fuego, pues los injustos no tienen defensores. Son infieles quienes dicen: «Dios es el tercero de una triada». No hay dios, sino un Dios único. Si no cejan en lo que dicen, realmente, quienes de entre ellos no creen, tocarán un tormento doloroso. ¿No volverán a Dios y le pedirán perdón?. Dios es indulgente, misericordioso. El Mesías, hijo de María, no es más que un Enviado; antes que él han existido enviados; su madre era verídica, ambos comían alimentos. Observa cómo aclaramos las aleyas a los cristianos; a continuación, fíjate en cómo se apartan. Di: «¿Adoraréis, prescindiendo de Dios, lo que no tiene para vosotros mal ni bien?». Dios es el Oyente, el Omnisciente. Di: «jGente del Libro! No exageréis en vuestra religión profesando algo distinto de la verdad; no sigáis los deseos de unas gentes que ya antes se extraviaron e hicieron extraviar a muchos y que se extraviaron de la buena senda».

Llama infieles a los que sostienen que el Mesías es Dios. Ataca, igualmente, la Trinidad. Jesús es sólo un enviado. Antes de él hubo otros varios.

En IX:30-31 se opone a la creencia de que el Mesías es Hijo de Dios. Acusa a los cristianos de haber tomado a sus doctores, a sus monjes y al Mesías por señores, prescindiendo de Dios. Este texto es muy importante, pues menciona a los monjes, a 
los doctores, al Mesías, como los señores de los cristianos. Muhammad conoce perfectamente la importancia de los monjes.

El Corán, V:85-88, dice así:

En los judíos y en quienes asocian encontrarás la más violenta enemistad para quienes creen. En quienes dicen: «Nosotros somos cristianos», encontrarás a los más próximos, en amor, para quienes creen, y eso porque entre ellos hay sacerdotes y monjes y no se enorgullecen. Cuando oyen lo que se hizo descender al Enviado, Mahoma, ves a sus ojos derramar lágrimas porque saben la verdad. Dicen: «Señor nuestro, creemos; inscríbenos con los testimonios. ¿Por qué no hemos de creer en Dios y en la verdad que nos ha enviado si ansiamos que nuestro Señor nos haga entrar en el Paraíso junto a la turbamulta de los justos?». Dios los recompensará por lo que dicen, haciéndoles entrar en los jardines en que corren, por debajo, los ríos, y permanecerán eternamente en ellos. Ésa es la recompensa de los benefactores. Quienes no creen y tratan de embusteras a nuestras aleyas, ésos serán huéspedes del Infierno.

Este párrafo es fundamental, pues indica que Muhammad tenía un conocimiento y, posiblemente, trató con sacerdotes y monjes cristianos, y que estaba en muy buenas relaciones con ellos, lo que explicaría el fuerte influjo monacal y cristiano en los orígenes del Islam.

Es muy probable que Muhammad, durante los años de matrimonio con su primera esposa, Hadijah, que comerciaba con Siria, visitase este país. Muhammad Ibn Gasir al Tabain, en su Vida de Muhammad, cuenta (VII) que enviaba cada año a Maysasah, persona de su plena confianza, con caravanas de mercancías a Siria. Hadijah mandó a Muhammad que acompañase a su esclavo a Siria, como lo hizo. Un anacoreta le dijo a Maysasah que no le llamara servidor, que era el profeta de Dios y el más perfecto entre las criaturas. La mercancía se vendió. Hadijah recomendó a Maysasah que lo llevara otras veces a Siria. No era la primera vez que visitaba Siria, donde conoció al monje nestoriano Bahira, que le profetizó que era el profeta de Dios (fig. 4).

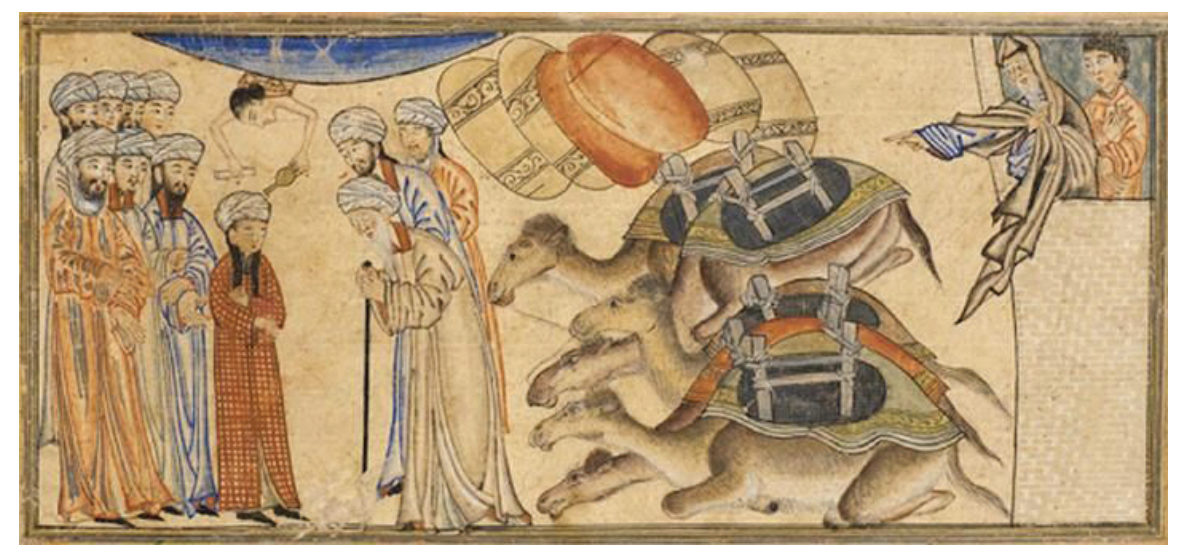

Fig. 4. El monje Bahira profetiza al joven Muhammad que era el profeta de Dios. Manuscrito. Royal Library. Edimburgo. 
En un texto anónimo titulado Contra Muhammad, datado en los siglos X-XI, se menciona un monje jacobista o monofisita, numerosos en Siria, que se relacionó con Muhammad. Juan Damasceno, en su Libro de las Herejías, afirma que Muhammad frecuentó un monje arriano, al que se debería la creencia de que Jesús no es Dios. Con seguridad, Muhammad visitó Siria y trató a monjes sirios, de ahí viene el parentesco entre Muhammad y el monacato sirio.

Según J. Vernet, en el prólogo a su edición del Corán, que es la que se maneja en este trabajo, escribe: "A la iglesia siria se debe el valor mínimo de los bienes terrenales, condenación severa del orgullo y de la ligereza de los incrédulos, puesta en guardia frente a los ricos; importancia del valor expiatorio de las limosnas, descripción del Paraíso, etc."

\subsection{MUHAMMAD Y LOS ASCETAS CRISTIANOS}

Muhammad llevó, al comienzo de su revelación, año 610, una vida ascética, vagabunda, a través de las montañas. Se retiró al monte Hisa, a una gruta. Allí recibió los primeros contactos con lo divino. Vagabundeaba desesperadamente por los precipicios de las montañas.

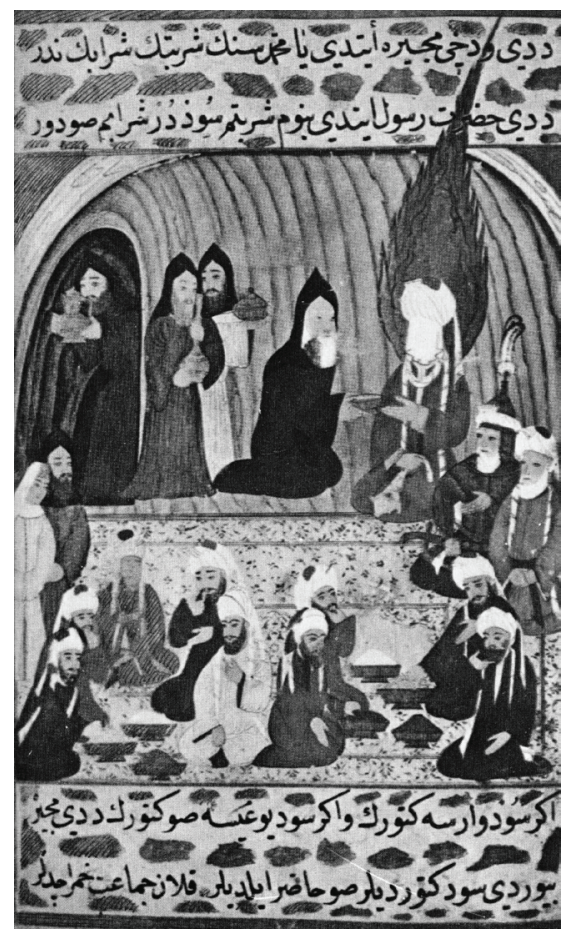

Fig. 5. Muhammad servido por monjes cristianos. Biblioteca turca. Universidad de Edimburgo. Según M. Eliade. 
Los ascetas sirios vivían frecuentemente en grutas y en montañas. En grutas fijaron su morada, como Juliano (II.2.4.7.18), Marciano (III.1) y Simeón el Viejo (VI.23.4). En montañas: Santiago (I.70), Marciano (III.1), Simeón el Viejo (VI.4), Macedonio (XIII.7.8), Eusebio (XVIII.1), Santiago (XXI.4), Juan (XII.1) y Simeón (XXVI.6).

Muhammad también llevó una vida ascética en las montañas, imitando no sólo a los grandes ascetas cristianos, sino a Jesús, que vivió cuarenta días en el desierto (Mt. 14), a Juan Bautista, que habitaba en el desierto (Mt. 11.7). El profeta Elías se refugió en el monte Horeb (1Re. 19.1-18).

Las comparaciones de aspectos fundamentales de la religiosidad del Islam con los del monacato sirio -hay otros varios puntos importantes que se dejan para un próximo trabajo- demuestran claramente que la religiosidad del Islam tiene un fuerte tinte monacal, que se debe al contacto directo de Muhammad y de los primitivos musulmanes con los monjes. Los árabes preislámicos tenían un contacto continuo con los monjes cristianos. Los únicos judeo-cristianos en la actualidad son los musulmanes y los abisinios. Como escribió Sayyed Husseyn Nasr: el Islam es una democracia de monjes casados.

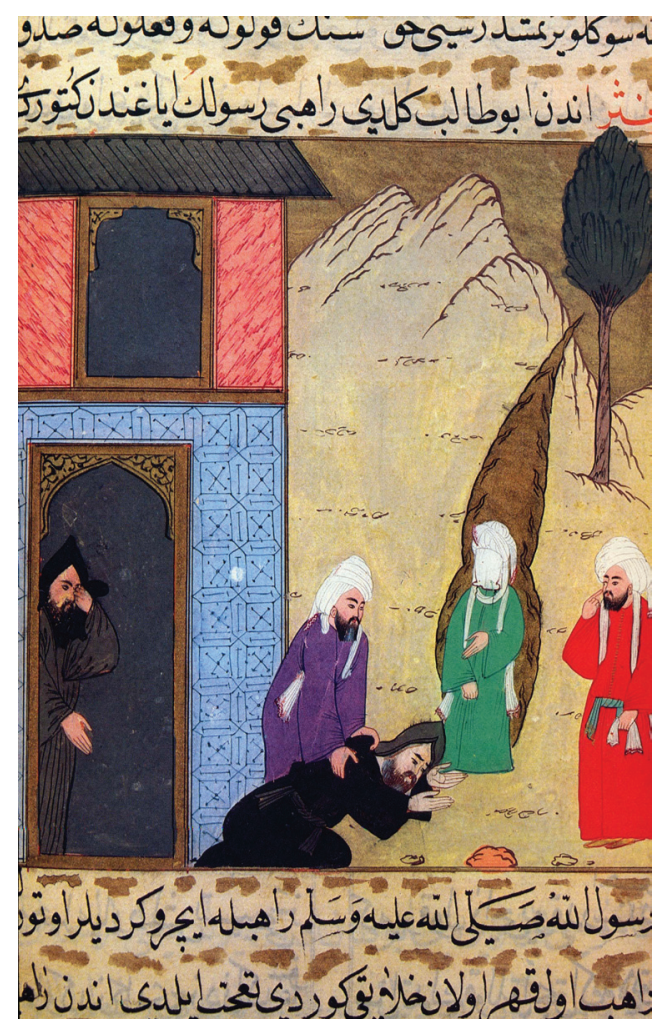

Fig. 6. Muhammad acude a los monjes cristianos a curarse de los ojos. Minitura de Siyer-iNebr. Museo Topkapi. Istambul. 


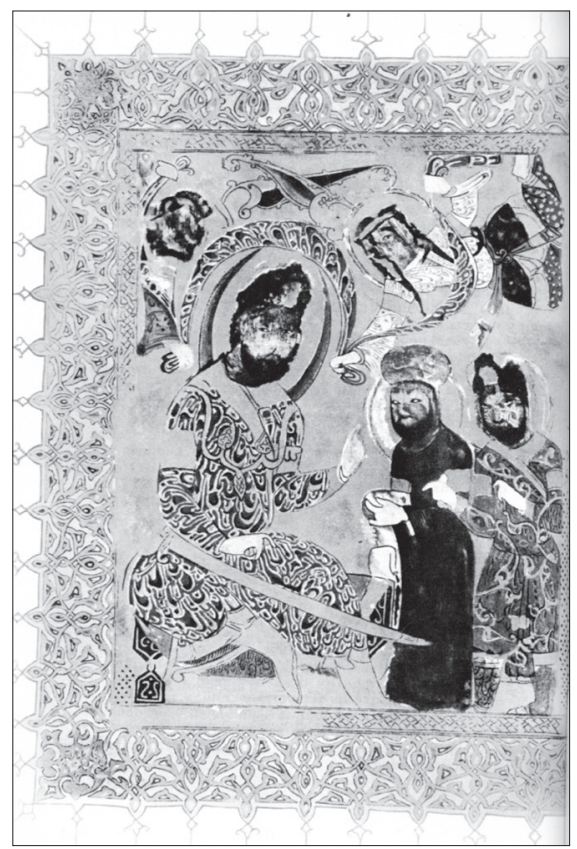

Fig. 7. Muhammad, un obispo cristiano y el prefecto de Nejran disputan sobre Jesús. Miniatura de Bagdad. Biblioteca Nacional de El Cairo.

No se les escapó a los artistas musulmanes la importancia de los monjes en Muhammad. Así, en una miniatura turca conservada en la Biblioteca de la Universidad de Edimburgo, se representa a Muhammad servido por los monjes (fig. 5). ${ }^{22}$ En una miniatura de la Vida de Muhammad de Siyer-i-Nebr, el profeta acude a los monjes a que le curen una enfermedad en los ojos (fig. 6). ${ }^{23}$ Los monjes charlan tranquilamente con los musulmanes en una pintura conservada en el Topkapi Sarayi Müzesi de Istanbul. ${ }^{24}$ En una miniatura siria, fechada en el s. XV, se representa el encuentro del joven Muhammad con el monje cristiano Bahira, que le profetizó que sería un gran profeta. ${ }^{25}$ En una miniatura de Bagdad, fechada en el año 1217, hoy en la Biblioteca Nacional de El Cairo (fig. 7), Muhammad disputa con el obispo cristiano y el prefecto de Nejran sobre Jesús. ${ }^{26}$ Es el más antiguo retrato conocido de Muhammad. Las excelentes relaciones de Jesús y Muhammad quedan reflejadas en la escena de una miniatura persa, de una obra de al-Burini (s. XVIII, Teherán, Biblioteca del Parla-

\footnotetext{
22 Eliade 1983, 360, fig. 31.

23 TANINDI 1998, lám. 12.

24 ATIL, ed., 1997, 206, fig. 102.

25 Dermenghem 1977, 15.

26 Dermenghem 1977, 107-108.
} 
mento), con Cristo y Muhammad cabalgando juntos para visitar a Abraham, que se asoma por la ventana de una torre. ${ }^{27}$

La religiosidad del Corán y la de los monjes sirios tienen muchos e importantes puntos de contacto. La cristología de Muhammad es la de los judeo-cristianos.

\section{BIBLIOGRAFÍA}

Abumalham, M. (2005): "Mística", [en] Abumalham (coord.), 2005, 71-189.

Abumalham, M. (COORD.), (2005): Textos fundamentales de la tradición religiosa musulmana, Barcelona, 71-189.

Akurgal, E. (COORd.), (1981): L'art en Turquie, Friburgo.

Andrae, T. (1955): Les origines de l'Islam et le Christianisme, París.

ARNÁLDEZ, A. (1990): Gesù nel pensiero musulmano, Turín.

Asín Palacios, M.

(1941): Huellas del Islam: Santo Tomás de Aquino, Turmeda, Pascal, S. Juan de la Cruz, Madrid.

(1981): El Islam cristianizado: estudio del "sufismo" a través de las obras de Ibn Arabi de Murcia, Madrid (1ª ed. Madrid, 1931).

(1981a): Vidas de santones andaluces: la "Epistola de la santidad" de Ibn Arabi de Murcia, Madrid ( $1^{\text {a }}$ ed. Madrid, 1933).

(1984): La escatología musulmana en la Divina Comedia, Madrid.

(1990): Sadilies y alumbrados, Madrid (ed. de Luce López-Baralt).

AтIL, E. (ED.), (1980): Turkish Art, Washington-New York.

BALDiCKs, J. (1989): Mystical Islam, Londres.

Bareu, A. (1989): Buda, Madrid.

Bell, R. - Watt, W. M. (1987): Introducción al Corán, Madrid.

Bellini, G. - Maschio, G. (1979): Ireneo di Lione. Contra le eresie e gli altri scritti, Milán.

Binns, J. (1994): Ascetics and Ambassadors of Christ. The Monasteries of Palestine, Oxford.

BLÁZquEZ, J. M ${ }^{\mathrm{a}}$

(1982): Intelectuales, ascetas y demonios al final de la Antigüedad, Madrid.

(2006): "Tolerancia e intolerancia religiosa en las cartas de Jerónimo", Antigüedad y Cristianismo 23, 467-473.

(2007): "La violencia religiosa originada por las decisiones del Concilio de Calcedonia (451) en los monjes del Oriente", [en] G. Bravo - R. González Salinero (eds.), Formas y usos de la violencia en el Mundo Romano, Madrid, 291-306.

(2007a): "Orígenes y el monacato", Bandue 1, 19-34.

(2007b): "Religión y Estado en el monacato oriental. Muhammad", Gerión 25/1, 501-533. (2008): "La violencia religiosa cristiana en la 'Historia Eclesiástica' de Sócrates durante los gobiernos de Teodosio II y en la 'Historia Eclesiástica' de Teodoreto de Cirro", Gerión 26/1, 453-490.

(2009): “Orígenes y su legado al Mundo Antiguo y al Mundo Moderno”, Gerión 27/1, 263-295.

27 Konzelmann 1983, lám. 14. 
(2010): "La violencia religiosa cristiana en la Tarda Antigüedad en los escritores Sócrates y Sozomeno. De Joviano a Teodosio II", [en] A. J. Domínguez Monedero - G. Mora Rodríguez (dirs.), Doctrina a magistro discipulis tradita. Estudios en homenaje al profesor Dr. Luis García Iglesias, Madrid, 327-353.

(e.p.): "La violencia religiosa cristiana en los escritores eclesiásticos. Desde Constantino a Juliano", [en] Homenaje al prof. Dr. A. Escudero, Madrid.

Brock, S. (COORD.), (1984): Syriac Perspectives on Late Antiquity, Londres.

Brown, P.

(1982): Society and the Holy in Late Antiquity, Nueva York.

(1997): El primer milenio de la cristiandad occidental, Barcelona.

(1998): "Holy Men", [en] A. Cameron - B. Ward-Perkins - M. Whitby (eds.), The Cambridge Ancient History, Vol. XIV: Late Antiquity: Empire and Successors, A.D. 425-600, Cambridge, 781-810.

Budert, H. J. - Günler Lerch, W. (1998): Turkei von der Antike zum Islam, Munich.

CAnivet, P. (1977): Le monachisme syrien selon Théodoret de Cyr, París.

Castillo, C. (1987): Abu l-Hasan al-As 'ari Kitab Sayarat al-Yaqin. Tratado de escatología musulmana. Estudio, edición, tradición, notas e índices, Madrid.

Chialà, S. - Cremaschi, L. (eds.), (2006): Giovanni di Damasco. Un padre al sorgere dell'Islam, Magnano.

Chitтy, D. J. (1980): Et le désert devint une cité... Une introduction à l'étude du monachisme égyptien et palestinien dans l'Empire Chrétien, Begrolless-en-Manges.

Cortés, J. (ED.), (2005): El Corán, Barcelona.

Crossan, J. D. (1994): Jesús: Vida de un campesino judio, Barcelona.

Cuerda Plaza, M. (2002): María, la mujer y la virgen del Corán, Madrid.

Dermenghem, E. (1977): Mahomet et la tradition islamique, Bourges.

Di SAlvo, M. (1999): Churches of Ethiopia. The Monastery of Narga Sellasé, Milán.

Eliade, M. (1983): Historia de las creencias y de las ideas religiosas, Madrid.

ERnst, C. W. (1999): Sufismo: una introducción esencial a la filosofía y la práctica de la tradición mística del Islam, Barcelona.

FIERRO, M.

(2005): "Polémicas anticristianas", [en] Abumalham (coord.), 2005, 155-170.

(2011): Abderramán III y el califato omeya de Córdoba, Donostia-San Sebastián.

Fuente, C. DE LA (2005): “La oración”, [en] Abumalham (coord.), 2005, 81-97.

Gabrieli, F., ET ALII (1988): Il Califato di Baghdad. La civiltà abbaside, Milán.

Gallico, A. (ED.), (1996): Teodoreto de Ciro, Storia dei monaci siri, Roma.

Ganivet, P. (1977): Le monachisme syrien selon Théodoret de Cyr, París.

Gaudefroy-Desmombynes, M. (1990): Mahoma, Madrid.

Granlich, R. (2004): Los místicos del Islam: mil años de textos sufies, Santander.

Guillaume, A. (1955): The life of Muhammad. A translation of Ibn Ishaq's Sirat Rasul Allah, Londres.

Hallstein, M. - Delius, P. (2001): El Islam. Arte y arquitectura, Barcelona. 
Hellenkerper Salies, G. (1988): "Die Mosaiken der Grossen Mosche von Damaskus”, [en] La Siria araba da Roma a Bizancio. XXXV. Corso di Cultura sull'arte Ravennate e Bizantina, Rávena, 295-313.

Hirschfeld, Y. (1992): The Judaean Desert Monasteries in the Byzantine Period, New Haven. Ibn Garir al-Tabari, M. (1989): Vita di Mahomet, Milán.

Ibrahim al-Ghabban, A. (2010): Routes d'Arabie. Arqueologie et Histoire du Royaume d'Arabie Saoudite, París.

Irwin, R. (ED.), (2010): Islam 4. Islamic Cultures and Societies to the End of the Eighteenth Century, Cambridge.

Juynboll: G. H. A. (1984): “Syria. Views of Emergent Islam”, [en] S. Brock (coord.), 1984, 9-21.

Konzelmann, G. (1983): Mahometo, Milán.

Küng, H. (2004): Islam. Passato, Presente e Futuro, Milán.

Le Coz, H. (1992): Jean Damascène. Écrits sur l'Islam, París.

Ling, M. (1989): Muhammad. Su vida basada en las fuentes más antiguas, Madrid.

Livne-Kafri, O. (1996): "Early Muslim Ascetics and the World of Christian Monasticisms", JSAI 20, 105-129.

López-Baralt, L. (1990): San Juan de la Cruz y el Islam, Madrid.

Martínez, F. J. (2008): "La literatura apocalíptica y las primeras reacciones cristianas a la conquista islámica en el Oriente", [en] G. Anes y Álvarez de Castrillón (coord.), Europa y el Islam, Madrid, 143-222.

Massignon, L. (1999): La pasión de Hallaj: mártir místico del Islam, Barcelona.

Massoun, G. (2006): "I primi dialoghi tra Islam e cristianesimo e il loro significati", [en] Chialà - Cremaschi (eds.), 2006, 117-127.

Mimouni, S. C. (1998): Le judéo-christianisme ancien. Essais historiques, París.

Mimouni, S. C. (2001), (COORD.), Le judéo-christianisme dans tous ses états. Actes du Colloque de Jerusalem, 6-10 juillet 1998, París.

Mohammed AbD-El-JALil, J. (2006): Testimone del Corano e del Vangelo, Milán.

MONFERRER, J. P. (2003): Apócrifos árabes cristianos, Madrid.

(2005): "Descripción del Paraíso", [en] Abumalham (coord.), 2005, 47-80.

Moreno, E. (2006): Conquistadores, Emires y Califas. Los Omeyas y la formación de alAndalus, Barcelona.

Nicholson, R. A. (2008): Los místicos del Islam, Palma de Mallorca.

Oliva, J. (1996): Libro de la escala de Mahoma, Madrid.

PAPAdopoulo, A. (1977): El Islam y el arte musulmán, Barcelona.

PAReJA, F. M. (1975): La religiosidad musulmana, Madrid.

PEÑA, I. (1990): La straordinaria storia dei monaci siri. Secoli IV-VI, Cinisello Balsamo.

Peña, I. - Castellana, P. - Fernández, F.

(1975): Les stylites syriens, Milán.

(1980): Les reclus syriens, Milán.

(1983): Les cénobites syriens, Milán. 
Piñero, A. - Gómez Segura, I. E. (2010): El Juicio Final en el cristianismo primitivo y las religiones de su entorno, Madrid.

Provençal, L. (1950): España musulmana hasta la caída del califato de Córdoba, 701-1033 de J.C. Historia de España IV, Madrid.

Robinson, F. (2007): El mundo islámico. Esplendor de una fe, Barcelona.

Robinson, CH. F. (ED.), (2010): Islam1. The Formation of the Islamic World. Sixth to Eleventh Centuries, Cambridge.

Rodríguez Mediano, F. (2005): "Vida de santos”, [en] Abumalham (coord.), 2005, 99-116.

Rousseau, Pн. (2000): "Monasticism", [en] A. Cameron - B. Ward-Perkins - M. Whitby (eds.), The Cambridge Ancient History, Vol. XIV: Late Antiquity: Empire and Successors, A.D. 425-600, Cambridge, 745-780.

Ruiz, A. (2004): Jesús. Una biografía, Barcelona.

SAHAS, D. J.

(1996): "Monastic Ethos and Spirituality and the Origins of Islam", [en] I. Ševčenko - G. G. Litavrin (ed.), Acts of XVIIIth International Congress of Bizantine Studies. Selected Papers: Main and Communications, vol. II, Shepherdstown, 27-39.

(2006): "L'Islam nel contesto della vita e della produzione letteraria di Giovanni di Damasco", [en] Chialà - Cremaschi (eds.), 2006, 97-115.

Scerrato, U. (1972): Grandes civilizaciones. Islam, Verona.

Schillebeekx, E. (1981): Jesús. La Historia de un vidente, Madrid.

Shimmel, A. (2002): Las dimensiones místicas del Islam, Madrid.

SKALI,F. (2006): Jesús en la tradición sufi, Madrid.

Stierlin, H. (2002): Islamic Art and Architecture, Vercelli.

SuÁrez, E. (2002): Conflictos religiosos. Pasado y presente, Valladolid.

TANind, Z. (1998): Islam Tasvir Sanatinda Hz. Muhammed'in Hayati, Eyliil.

Vernet, J. (1987): Mahoma, Madrid.

Vernet, J. (ED.), (1991): El Corán, Barcelona.

Vitray-Meyerovitch, E. DE (2002): I mistici dell'Islam, Parma.

VoöBus, A. (1958-1960): History of Asceticism in the Syrian Orient, vols. I-II, Lovaina.

WATT, W. M.

(1958): Mahomet à la Mecque, París

(1959): Mahomet à Medine, París.

VV.AA. (2001): El esplendor de los Omeyas cordobeses, Granada. 